\title{
Advanced Concrete Steam Accumulation Tanks for Energy Storage for Solar Thermal Electricity
}

\author{
Cristina Prieto ${ }^{1,2, * \mathbb{D}}$, David Pérez Osorio ${ }^{1}$, Edouard Gonzalez-Roubaud ${ }^{1}$, Sonia Fereres ${ }^{1}$ (D) \\ and Luisa F. Cabeza ${ }^{3, *}$ (D) \\ 1 Abengoa Energía, Calle Energía Solar, 1, 41014 Sevilla, Spain; davidperez.osorio@abengoa.com (D.P.O.); \\ edouard.gonzalez@abengoa.com (E.G.-R.); sonia.fereres@abengoa.com (S.F.) \\ 2 Department of Energy Engineering, University of Seville, Calle San Fernando, 4, 41004 Sevilla, Spain \\ 3 GREiA Research Group, University of Lleida, Pere de Cabrera s/n, 25001 Lleida, Spain \\ * Correspondence: cprieto@us.es (C.P.); luisaf.cabeza@udl.cat (L.F.C.)
}

Citation: Prieto, C.; Pérez Osorio, D.; Gonzalez-Roubaud, E.; Fereres, S.; Cabeza, L.F. Advanced Concrete Steam Accumulation Tanks for Energy Storage for Solar Thermal Electricity. Energies 2021, 14, 3896. https://doi.org/10.3390/en14133896

Academic Editor:

Dimitrios Katsaprakakis

Received: 27 May 2021

Accepted: 24 June 2021

Published: 28 June 2021

Publisher's Note: MDPI stays neutral with regard to jurisdictional claims in published maps and institutional affiliations.

Copyright: (c) 2021 by the authors. Licensee MDPI, Basel, Switzerland. This article is an open access article distributed under the terms and conditions of the Creative Commons Attribution (CC BY) license (https:// creativecommons.org/licenses/by/ $4.0 /)$.

\begin{abstract}
Steam accumulation is one of the most effective ways of thermal energy storage (TES) for the solar thermal energy (STE) industry. However, the steam accumulator concept is penalized by a bad relationship between the volume and the energy stored; moreover, its discharge process shows a decline in pressure, failing to reach nominal conditions in the turbine. From the economic point of view, between $60 \%$ and $70 \%$ of the cost of a steam accumulator TES is that of the pressure vessel tanks (defined as US\$ $/ \mathrm{kWh}_{\mathrm{th}}$ ). Since the current trend is based on increasing hours of storage in order to improve dispatchability levels in solar plants, the possibility of cost reduction is directly related to the cost of the material of pressure vessels, which is a market price. Therefore, in the present paper, a new design for steam accumulation is presented, focusing on innovative materials developed specifically for this purpose: two special concretes that compose the accumulation tank wall. Study of dosages, selection of materials and, finally, scale up on-field tests for their proper integration, fabrication and construction in prototype are the pillars of this new steam accumulation tank. Establishing clear and precise requirements and instructions for successful tank construction is necessary due to the highly sensitive and variable nature of those new concrete formulations.
\end{abstract}

Keywords: storage tank; accumulator; steam; storage; concrete; insulation refractory; high-strength; self-compacting concrete; construction

\section{Introduction}

Large-scale thermal energy storage (TES) is a key component of concentrating solar power plants (CSP), offering energy dispatchability by adapting the electricity power production to the demand curve [1]. The industry is looking for more economical and efficient TES systems, especially for process heat applications between $150-250{ }^{\circ} \mathrm{C}$. New decarbonization strategies worldwide promote the solarization of the process heat, where direct steam generation is one of the most efficient technologies [2]. However, the need for effective steam storage penalizes this application.

Commercial solar thermal electricity plants today implement only two TES technologies: steam accumulators and molten salts storage [3].

Parabolic trough plants with thermal oil and molten salt towers use two tanks of molten salts as storage system. Molten salt is the most widespread heat transfer fluid for thermal energy storage in CSP commercial applications due to its good thermal properties and reasonable cost [2]. Direct TES systems, i.e., where the storage fluid is the same as that directly heated by the concentrated solar radiation, have the advantage of reducing system losses and complexity by eliminating heat exchangers between the heated and the storage media; this is used in commercial parabolic trough plants [4].

Direct steam generation plants use steam accumulators, also known as Ruth accumulators [5]. In these systems, the steam is directly stored at high pressure in accumulator 
tanks. The equipment is charged with the surplus saturated steam produced by the plant. During the discharge, steam is produced by lowering the pressure of the saturated liquid stored within the tank. Steam has the added benefit of being a common working fluid for power generation cycles, also eliminating the need for heat exchangers between the solar field and the power block.

First generation STE towers use saturated steam technology. As of January 2016, there were only two commercial CSP plants in operation using steam accumulator TES: PS10 and PS20, both located in Spain. They started commercial operation in 2007 and 2009 , respectively, and they were the first two commercial central receiver solar plants in the world and the starting point for the operation of the direct steam generation (DSG) technology. Figure 1 represents schematically a flow diagram of the PS10 and PS20 direct steam generation tower plant with a steam accumulator thermal energy storage system.

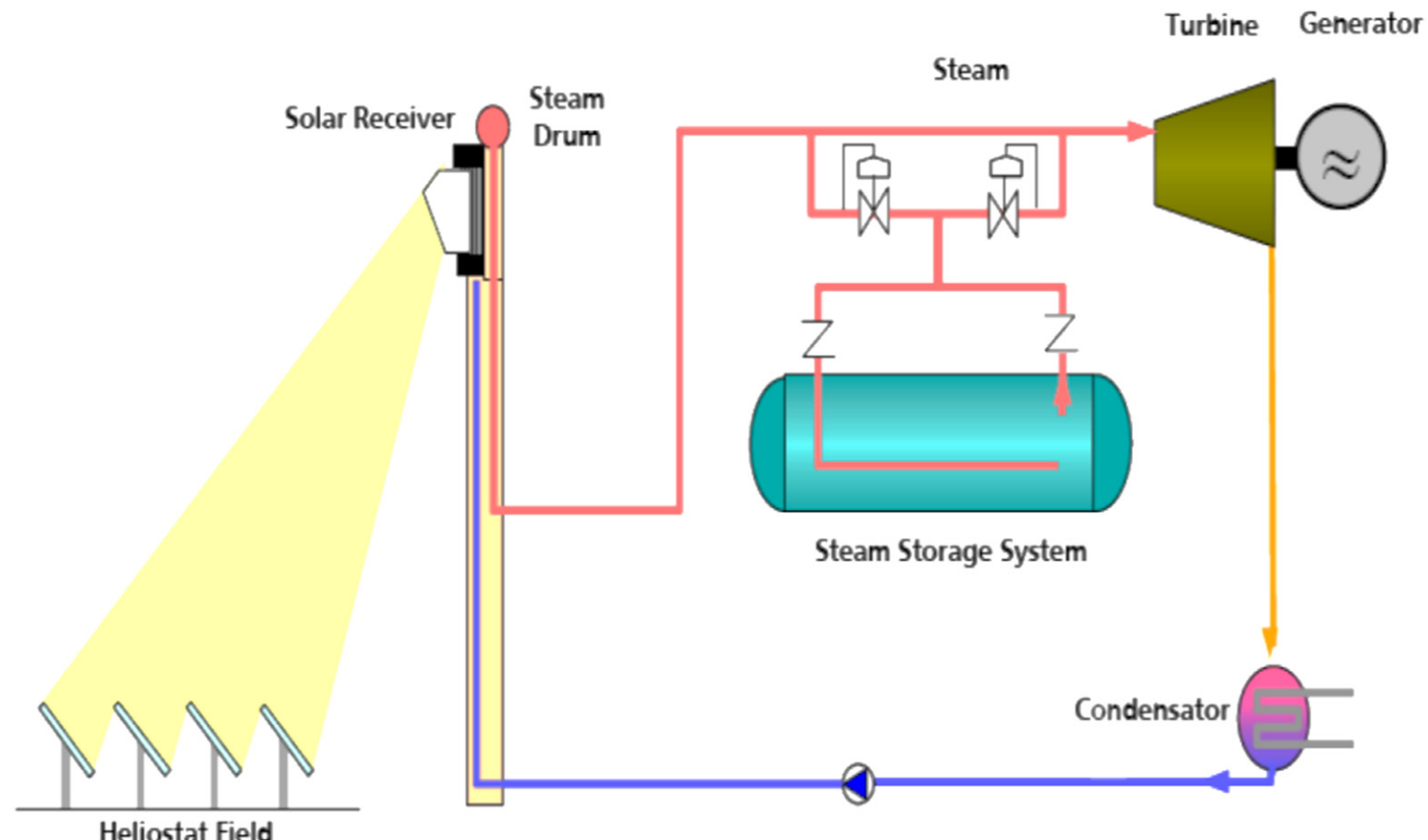

Figure 1. Schematic flow diagram of a direct steam generation tower plant (saturated steam) with steam accumulator thermal energy storage system (Source: Abengoa).

The PS10 central receiver plant uses a 11 MWe saturated steam Rankine cycle with steam accumulator thermal energy storage. PS10 has 624 heliostats $\left(120 \mathrm{~m}^{2}\right.$ each) for a total reflective surface of around $75,000 \mathrm{~m}^{2}$. It is arranged in circular rows around the tower, concentrating solar radiation on a saturated steam cavity receiver placed on top of a $115 \mathrm{~m}$ tower. The storage system provides $20 \mathrm{MWh}$ of storage capacity, giving $50 \mathrm{~min}$ effective operational capacity at $50 \%$ turbine workload. The system has four tanks that are operated sequentially in relation to their charge status. During full load operation of the plant, the steam accumulators are charged with a proportion of the steam produced at the receiver at $250{ }^{\circ} \mathrm{C}$ and 45 bars. When a transient period needs to be covered, energy from the saturated water will be recovered at variable pressure. Figure 2 shows the steam accumulators at PS10.

The PS20 central receiver plant has 1255 heliostats (with a surface of $120 \mathrm{~m}^{2}$ each) and uses the same technology as PS10 but its power cycle reaches 20 MWe with an equivalent storage capacity of $50 \mathrm{~min}$ at $50 \%$ turbine workload using two steam accumulators that are discharged in sequence. 


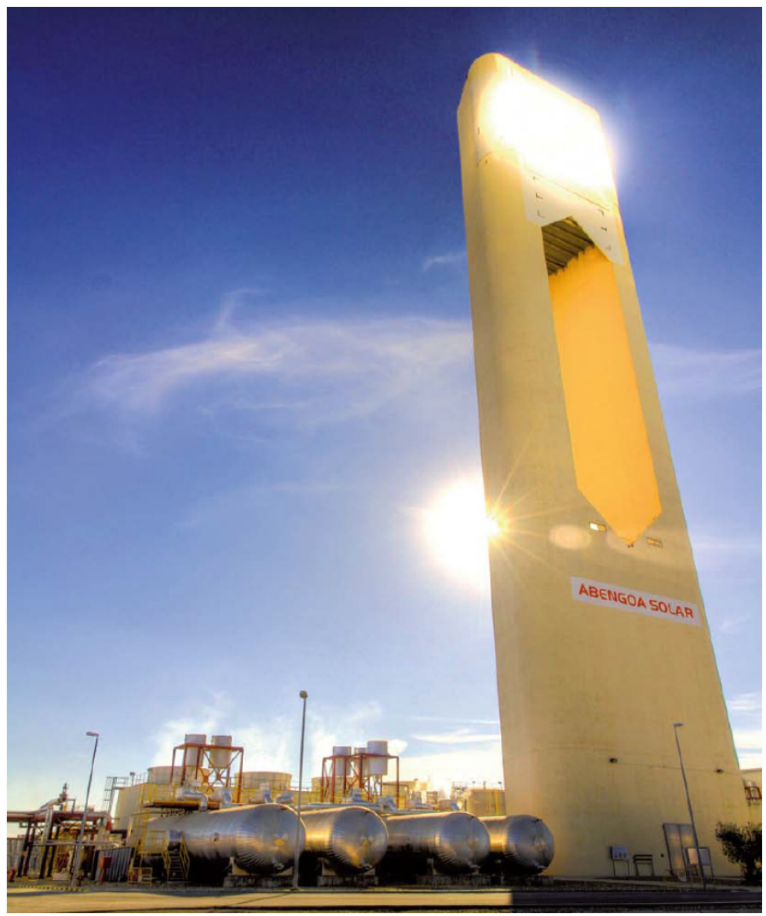

Figure 2. Steam accumulators of PS10 plant (Source: Abengoa).

Superheated steam is used in the second generation of STE direct steam towers. This technology uses a second receiver that re-heats the steam produced by the first receiver (evaporator) to reach higher temperatures. The live steam feeding the turbine can reach $540{ }^{\circ} \mathrm{C}$ and 130 bars of pressure, increasing by $30 \%$ the efficiency of the power cycle compared to first generation PS20.

Khi Solar One is a 50 MWe commercial tower plant located in Upington (South Africa) and put into operation in 2016 (Figure 3). It is a second-generation direct steam plant with a steam accumulator TES. It has a tower $205 \mathrm{~m}$ high and uses 4120 heliostats with a surface area of $140 \mathrm{~m}^{2}$ each. The storage capacity of Khi Solar One is 2-h using 19 steam accumulator tanks.

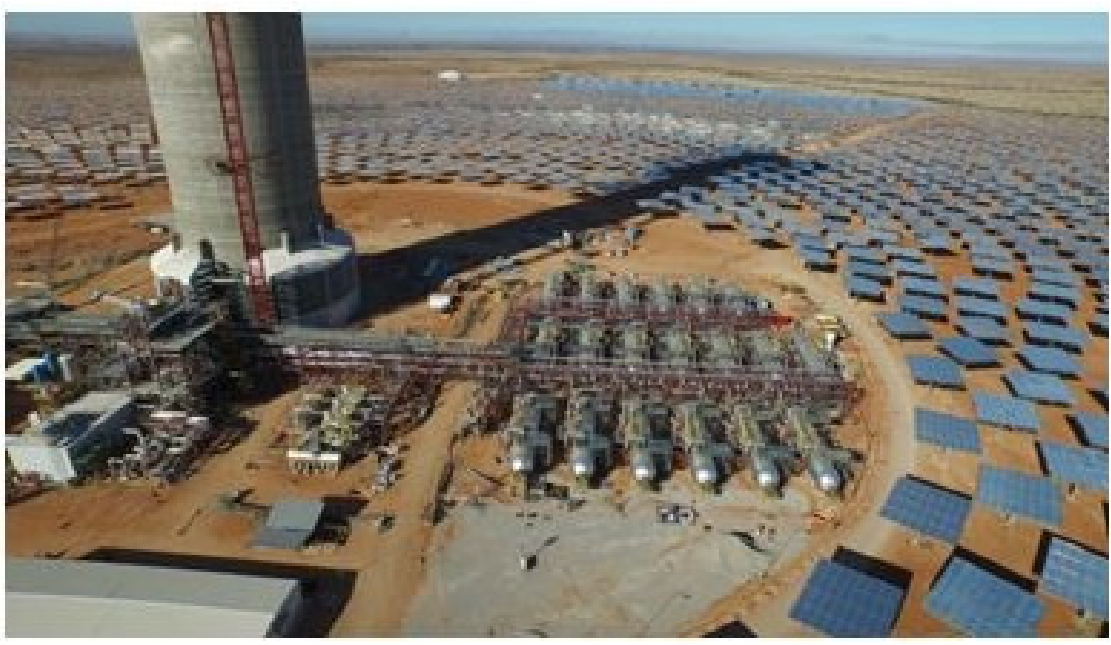

Figure 3. Steam accumulators of 50 MWe Khi Solar One plant (Source: Abengoa).

Figure 4 shows a schematic flow diagram of the Khi Solar One plant with a superheated direct steam tower and steam accumulator TES. 


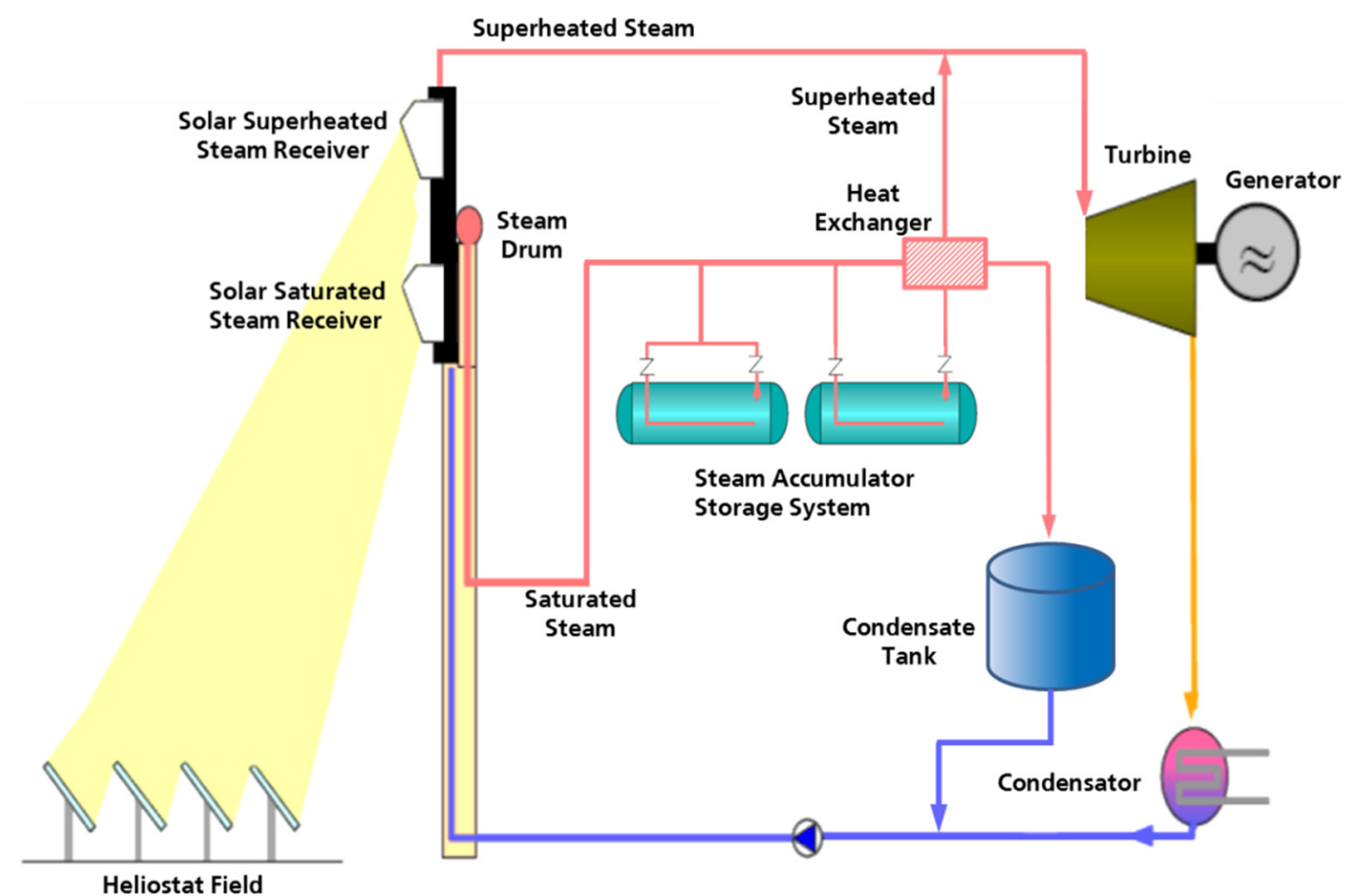

Figure 4. Scheme of $50 \mathrm{MW}$ Khi Solar One plant (superheated steam) with steam accumulator TES system.

The state-of-the-art for steam accumulators uses steel as constructive material to resist high pressure and high temperature water/steam [6]. Steam accumulation tanks are generally cylindrical with elliptical ends and are manufactured from boiler plate. One of the main advantages is that the storage fluid is water, avoiding uncertainty in the price of the storage medium. Steam accumulators are a proven option for compensation of transients and mid-term storage to meet supply/demand curves when there is no radiation, due to their fast reaction times and high discharge rates. Nevertheless, the main disadvantages of steam accumulators are the low volumetric energy density stored as well as the discharge process, which shows a decline in pressure, unable to nominal conditions in the turbine. From the economic point of view, the main cost of a steam accumulator TES is that of the pressure vessel tanks, which can account for $60 \%$ to $70 \%$ of the TES total thermal costs (in $\mathrm{US} \$ / \mathrm{kWh}_{\mathrm{th}}$ ) [3]. In general, carbon steel is the most usual material used for the fabrication of steam accumulation tanks. The design presented in this paper seeks to reduce costs by substituting carbon steel with cheaper constructive materials such as concretes. However, the material selected must withstand a combination of pressure (higher than 100 bars), temperature (higher than $300^{\circ} \mathrm{C}$ ), and long-term thermal cycling while maintaining good durability against chemical attack.

The proposed innovative design for the accumulator tank consists of a double-walled cylinder accumulation tank with a post-tensioned concrete layer (a structural layer, made of high-strength self-compacting concrete (HSSCC)) able to withstand high tensile stresses, and an insulating refractory concrete layer (a thermal stability layer) isolating the structural layer from the high temperature steam which can jeopardize the mechanical properties of the outer layer and corrode its steel reinforcements. This multi-layer concept allows higher working temperatures and pressures, at lower cost if it is compared to the current commercial steel steam accumulation tanks.

A similar multilayer concept has been used to contain nuclear reactors [7]. These structures tend to use post-tensioned concrete walls, but their working pressure range is 10 times lower than required in solar thermal applications (higher than 100 bars). In case of a loss of coolant accident (LOCA) the heat emitted from the reactor vessel is conducted through the steel shell to the concrete wall which is exposed to atmospheric 
pressure; if this concrete is heated excessively, cracking phenomena could occur due to large thermal gradients generated inside the wall. In order to solve this problem an intermediate refractory concrete layer is installed. Refractory concretes can resist five-six times higher temperatures than required (higher than $300^{\circ} \mathrm{C}$ ), but they are not generally working with internal pressures of such magnitudes.

Double-walled systems can be found, with smaller thicknesses for less demanding combinations of pressure and temperature, and in general the refractory wall does not have any mechanical or structural properties, which would prevent the use of insulating liners.

There are also vessels and tanks that use post- and pre-tensioned concrete walls with different purposes, such as water and oil storage or natural gas containment [8]. Clinker and/or cement silos, among others, use prestressed concrete walls, but the pressure and temperature parameters are lower than required in solar thermal applications.

On the one hand, the development of high-strength self-compacting concrete (HSSCC) is the result of the demand for better performance in present-day structures employing new chemical admixtures. High-strength concretes are those whose characteristic compressive strength exceeds $50 \mathrm{MPa}$ (a typical value [9], depending on the standards in different countries). Self-compacting concretes are those compacted by the action of their own weight, without any external vibration energy and was introduced in the 1980s to obtain seismic-resistant and durable structures without the need for qualified labor for its compaction [10]. To achieve elevated flowability and appropriate cohesion, it was essential to combine selected grading distributions with very efficient super-plasticizer admixtures. This was the key in their evolution until current polycarboxylate formulations allowed a satisfactory behavior of fresh concrete [11].

Achieving simultaneously self-compacting and high strength properties requires a high accuracy in establishing a dosage, especially because these are not reached by similar dosing, although combination is possible. Current self-compacting concretes also have elevated compressive strength values, higher than conventional ones, even inside highresistant classification (more than $50 \mathrm{MPa}$ [9]). The problem emerges when trying to reach values higher than $100 \mathrm{MPa}$ while keeping self-compacting properties, as required for the design of the steam accumulation tanks developed by Abengoa, since there is no product able to cope with both. In a simple search of catalogues and technical data sheets from well-known companies of said industry, it is possible to find similar, but not superior, concretes (Table 1). The only concrete products that could lead these requirements are Ductal from Lafarge and Durcrete. Ductal can reach $180 \mathrm{MPa}$ with self-compacting properties, but the cost is not affordable for steam accumulation tank application; Durcrete assures self-compacting properties with $150 \mathrm{MPa}$, but its workability and fabrication imply low volumes and unscalable procedures (supply in bags for mixing on site).

Table 1. Properties of commercial concretes.

\begin{tabular}{cccc}
\hline \multicolumn{2}{c}{ Commercial Concrete } & $\begin{array}{c}\text { Compressive } \\
\text { Strength }\end{array}$ & Self-Compacting \\
\hline \multirow{2}{*}{ Lafarge } & Agilia & $25-40 \mathrm{MPa}$ & Yes \\
& UltraSeries & $>100 \mathrm{MPa}$ & No \\
Ductal & $180 \mathrm{MPa}$ & Nos \\
Portland-Valderrivas & High strength & $100 \mathrm{MPa}$ & Yes \\
Hanson & Self-compacting & $<70 \mathrm{MPa}$ & Yes \\
Cemex & H-resist & $<50 \mathrm{MPa}$ & No \\
FYM & Hormiresist & $100 \mathrm{MPa}$ & Yes \\
Promsa & i.flow & $<30 \mathrm{MPa}$ & No \\
& High resistance & $120 \mathrm{MPa}$ & Yes \\
& Self-compacting & $<50 \mathrm{MPa}$ & Yes
\end{tabular}

On the other hand, insulating concretes are widely known in building engineering, raw material manufacturing and power plant equipment, currently developed as standard 
commercial products. The objective of these insulating products is to restrain and avoid thermal effects. The majority are focused on conventional pre-manufactured elements such as panels, bricks [12] or blocks [13]. Research studies regarding new insulating concretes have been carried out in order to make more sustainable and eco-friendly materials such as rice husk [14-16] or foams [16-18].

Nevertheless, much more research on lightweight concretes has been recently carried out to increase their lightweight characteristics [17,19] and better structural performance [20] in order to reduce loads on structures. The most commonly used solution to innovate in lightweight concretes is to incorporate new lightweight aggregates (LWA), replacing normal aggregates (NA) in the dosage components [21-23]. One of the most popular additions to this type of concrete is fly ash aggregates [24,25].

After an extensive search of the refractory industry, no commercial product was found to meet both the high thermomechanical values of thermal conductivity and compressive strength required for this design. It is possible to find similar thermal conductivity but insufficient values of compressive strength, and exactly the opposite premise, concrete of similar compressive strength but insufficient thermal conductivity (Table 2). This table shows that the range of commercial refractory concretes is limited. Concretes with high compressive strength have too high thermal conductivities and vice versa. Therefore, these low compressive strength concretes are not used for structural purposes, only for thermal insulation purposes in non-structural constructions, hence the need to develop in this work a new refractory concrete with high structural performance.

Table 2. Thermal conductivity of commercial concretes.

\begin{tabular}{ccc}
\hline Commercial Concrete & $\begin{array}{c}\text { Thermal Conductivity } \\
(\mathbf{W} / \mathbf{m} \cdot \mathbf{K})\end{array}$ & Compressive Strength (MPa) \\
\hline Alosil A-124 B & - & $4-6$ \\
Promacast MW 1.4 HT & 0.34 & $6-10$ \\
Promacast FC 40 & 0.72 & $30-40$ \\
Horlite 1-2-4 B & $2-3$ & $4-5$ \\
Horlite 900 LI & - & $5-7$ \\
Horsigel 9362 & 1.54 & $5-7$ \\
Horlite 1300 SF & 0.44 & 1.8 \\
Thermedia 0.6 & 0.54 & 25 \\
\hline
\end{tabular}

Another challenge is that new concrete formulation development in a laboratory setting is only the first step for materials development. It is a challenge to achieve very stringent mechanical and/or thermal properties later, in the field, in an uncontrolled environment and at large scale. Thus, another objective of this research is to demonstrate experimentally that it is possible to elaborate concrete on-field, with the materials, dosage and process determined at small scale in the laboratory and to characterize the variability in its properties.

To sum up, it is concluded that thermal energy storage systems in CSP are necessary to offer dispatchability. Currently, molten salts are the most widely used commercial system, while net steam storage still needs to lower costs. The objective of this study is to design a lower-cost accumulator; therefore, a cheaper construction material is selected, i.e., concrete. A new design of the steam accumulation tank is shown, deploying a combination of layers: two concrete walls with an inner metallic shell. The interior wall has a purely thermal purpose; it is an insulating layer to reduce the temperature that reaches the structural concrete. There is no connection between the structural layer and the refractory layer to avoid thermal bridges that would compromise the overall tank system. The structural wall could be damaged at high temperature. The refractory concrete was made once the concrete of the external layer had been built and hardened. 
Internally, to protect the refractory concrete layer, a high-performance metallic liner was designed, which avoids contact of steam with the concrete, reducing the risk of contamination.

\section{Conceptual Design}

A cylindrical body and elliptical top are the starting point for the tank design. The inner working pressure $(p>100 \mathrm{bar})$ and temperature $\left(\mathrm{T}>300^{\circ} \mathrm{C}\right)$ drive the geometrical, structural, and mechanical requirements of the steam accumulation tank. The main design constraint is the need for a concrete wall that can withstand the high tensile stress caused by the inner pressure, while avoiding excessive thermal heating on that wall. This is the reason for a concrete double-wall design. The outer wall is a thick, high-strength posttensioned concrete; the inner wall is made of refractory concrete able to withstand high temperatures with an internal steam-protective shell. Both concrete walls are adjacent but not joined together.

The high-strength wall has a double mission: first, to act as a compressive force on the inner layer (refractory concrete) constraining its free expansion due to the inner thermal loads. The second objective of the high-strength wall is to distribute tensile stresses generated by the high internal pressure so that the sum of the compressive stresses generated by the thermal loads, plus the tensile stresses produced by the pressure, is a net compressive stress. A compressive stress state in this wall avoids a cracking phenomenon which could result in a risk for structure durability (fatigue, chemical action for steam by voids, etc.). Hence, the outer wall, stiffer than the inner wall, absorbs most of the traction.

Even though a higher thickness produces fewer tensions in the wall by increasing the load distribution area, tensile stresses generated by inner pressure increase in proportion to the radius. So, it is essential to search for an optimum relation between wall thickness, post-tensioning strength, and the characteristic compressive strength of concrete.

The inner refractory (insulation) concrete wall prevents the temperature inside the tank from reaching the double-wall interface, avoiding the thermal expansion of the outer wall. Moreover, if this high temperature reaches the high-strength concrete wall, it would alter the mechanical properties of the high-strength concrete and effect the durability of the exterior wall as well as its active (post-tensioning cables) and passive reinforcement (steel bars). It is crucial that this insulating refractory concrete has a low thermal expansion coefficient, so that the that inner compression generated by constraining the thermal expansion is not higher than the tensile stress produced by the inner accumulation pressure, balancing each other.

Regarding the concrete quality, both will be compressed continuously during operation. Thus, their compressive strength is a key factor. However, the wall stiffness influences the generation of tensile and compressive stresses, so the elastic modulus of both concretes is also a parameter to optimize.

The anchorage zones of the post-tensioning tendons must withstand the concentrated loads that are transmitted by the post-tensioning rings. The number and distribution of these anchorage zones is defined by distribution of the tendons. Due to the cylindrical curvature, friction losses occur between the tendons and the sheaths, reducing the posttensioning force from the middle of the cables (tendons tensioned at both ends). In order to avoid failures by concrete crushing, a minimum height between rows in the anchorage zones must be established. These considerations lead to a design with four anchor points, distributing seven tendon rings in four alternating superposed systems as shown in Figure 5.

The design is associated with a complete constructive procedure, which establishes the first development of the external high-strength wall by means of climbing formworks. The next stage is post-tensioning procedure of $85 \%$ of the tendons ( 6 of 7 tendon rows). Next, the inner refractory wall is also built by the means of climbing formworks. Then, the remaining row of tendons is post-tensioned to complete the process with the required pre-compression of the refractory wall. Finally, the semi-spherical dome is built at the top 
of the accumulation tank, as shown in Figure 6 and Table 3. The tendon system consists of several high rows of seven semi-circular tendons. These rows were arranged in an alternating rotating pattern, so that "compression circles" were completed in the structural wall of the tank as it rose in height. For their construction, stainless steel pipes were used as "inner ducts" in the concrete. Once each height was concreted, the tendons were inserted into these tubes and then a compression grout was injected to prepare the tendons for stressing, which was done once the tank was fully constructed.

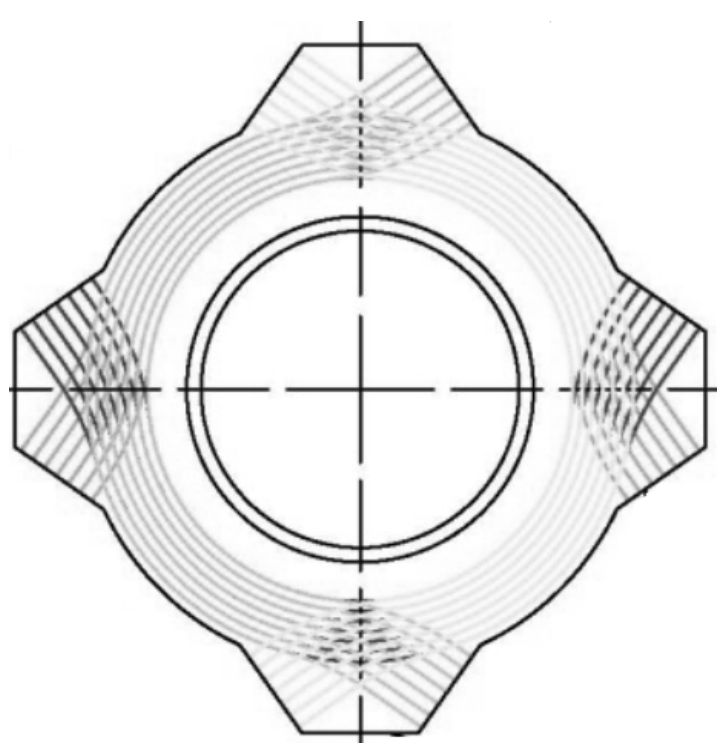

Figure 5. Tendon rings established in the accumulation tank.

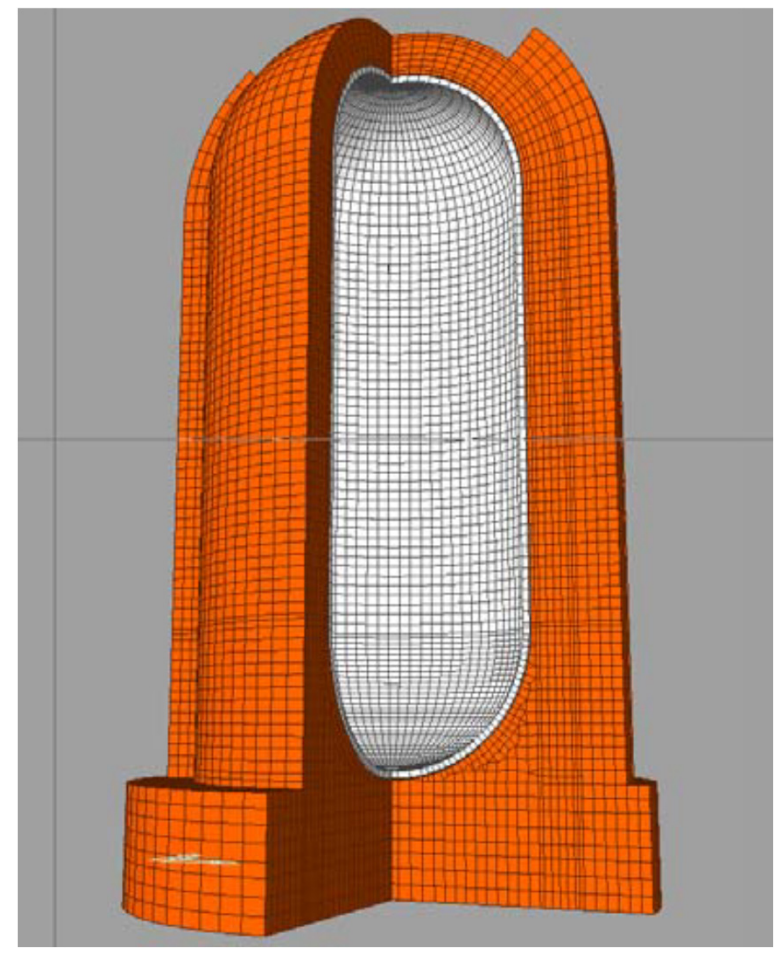

Figure 6. Accumulation tank conceptual design. 
Table 3. Conceptual design parameters.

\begin{tabular}{|c|c|c|}
\hline \multicolumn{2}{|c|}{ Tank Capacity } & \multirow{2}{*}{$\begin{array}{c}3500 \mathrm{~m}^{3} \\
40 \mathrm{~m}\end{array}$} \\
\hline \multirow{3}{*}{ Inner refractory concrete wall } & Height & \\
\hline & Inner radius & $5.5 \mathrm{~m}$ \\
\hline & Thickness & $0.45 \mathrm{~m}$ \\
\hline Outer concrete wall & Thickness & $3.8 \mathrm{~m}$ \\
\hline
\end{tabular}

The new steam accumulation design requires, for its external wall, a post-tensioned high-strength concrete in order to withstand the strong tensile stresses generated by inner steam pressure. Given the large thickness and the strong active reinforcement needed in this external wall, passive reinforcing steel bars are required. These elements make the concrete infiltration and compacting process more difficult and could create voids. For all these reasons, the high-strength concrete must also be self-compacting.

Essential properties to be sought in both concretes are the correct distribution and time evolution of temperature through the wall thicknesses. The objective is not to exceed a maximum temperature at the interface of both concretes.

This insulating wall must be compressed continuously to assure durability (no cracking) and waterproofing properties. Thermal loads produce an expansion that is constrained, staying internally compressed. Thus, at least a conventional compressive strength ( $>20-25 \mathrm{MPa}$ for lightweight/ordinary concretes) is required for the new insulating refractory concrete.

This "self-compression" phenomenon of the refractory wall, due to thermal loads, is the process that requires the greatest level of control, because it is responsible for strong compression in a wall with a desirable minimum thickness. That is why a low thermal expansion coefficient is required for the refractory concrete, leading to a compromise between the cost of increasing thickness and a decrease in the thermal expansion coefficient. A low porosity and a minimum variation of mechanical properties at high temperatures $\left(>300{ }^{\circ} \mathrm{C}\right)$ are essential. Additionally, the thermal properties of the refractory concrete must be tested under real cycling conditions.

Specific technical requirements were defined for the liner:

- $\quad$ Yield strength (MPa): $890 \mathrm{MPa}$

- Tensile strength: 940-1100 MPa

- $\quad$ High Strength Steel (RQT $\left.901^{\circledR}\right)$.

\section{Materials and Methods}

\subsection{Materials}

As stated above, concrete is the construction material for both tank walls. The outer wall is designed with a reinforced high-performance concrete with self-compacting properties and the inner wall is designed with a special refractory concrete. Both compositions are based on non-commercial concretes because concrete state-of-the-art does not solve the problems of the extreme conditions demanded by the solar thermal industry.

The refractory concrete used (Table 4) is developed by Abengoa. based on the performance required for future commercial applications:

- Thermal conductivity: $\lambda=0.2 \mathrm{~W} / \mathrm{m} \cdot \mathrm{K}$.

- Compressive strength (90 days): $\mathrm{Rc}(90 \mathrm{~d})=20 \mathrm{MPa}$ 
Table 4. Refractory concrete developed.

\begin{tabular}{|c|c|c|c|}
\hline Components & $\mathrm{kg} / \mathrm{m}^{3}$ & Origin & Class \\
\hline CEM I-52.5-R & 432 & La Unión & Cement \\
\hline Fly ash & 103 & CENCATRA & Addition \\
\hline Glenium C303 SCC & 4.37 & BASF & Superplasticizer Additive \\
\hline Sand AE0/4 Clay ** & 271 & ARCIRESA & Expanded clay \\
\hline Gravel AE3/10 Clay ** & 204 & ARCIRESA & Expanded clay \\
\hline Water & 271 & Concrete plant & Water \\
\hline
\end{tabular}

** dry base.

The high-performance concrete used (Table 5) is developed by Abengoa, based on the performance required for future commercial applications:

- $\quad$ Compressive strength (28 days): Rc $(28 \mathrm{~d})=100 \mathrm{MPa}$

- $\quad$ Self-compacting properties, as stated on EHE Spanish Concrete Instruction (annex 17, where materials description, calculation specifications and fabrication properties are established) [9].

Table 5. High performance concrete developed.

\begin{tabular}{cccc}
\hline Components & $\mathbf{k g} / \mathbf{m}^{\mathbf{3}}$ & Origin & Class \\
\hline CEM I-52.5-R/SR & 500 & HOLCIM & Cement \\
Fly ash & 100 & SUBICOSA & Addition \\
Metakaolin & 55 & ARCIRESA & Addition \\
Limestone Filler & 30 & - & Addition \\
Silica fume & 55 & SIKA & Addition \\
Polypropylene fibers & 0.6 & SIKA & Addition \\
Sand $0 / 4^{* *}$ & 788 & Quintos quarrel & Natural Aggregate \\
Gravel $2 / 8^{* *}$ & 928 & Quintos quarrel & Natural Aggregate \\
Viscocrete $20 \mathrm{H}$ & 13 & SIKA & Superplasticizer additive \\
Retarder $(1.0 \%)$ & 5 & SIKA & Retarder additive \\
Water & 160 & Concrete plant & Water \\
\hline ** & & &
\end{tabular}

** dry base.

With these dosage concretes developed can be classified as (following EHE terminology):

- Refractory concrete: HL-30/B/10

- High performance concrete: HAR-100/AC/8

The liner uses high strength steel, RQT901 (TataSteel ${ }^{\circledR}$ ) with tensile strength $890 \mathrm{MPa}$.

\subsection{Lab-Scale Concrete Development}

For the tank construction, the concretes are fabricated in a plant located in Aznalcollar town, province of Seville (Spain), near the Abengoa facilities where the pilot tank construction site is located. The fabrication method follows the conventional rules of EHE Spanish Concrete Instruction [9].

\subsubsection{Refractory Concrete Fabrication}

Before proceeding with the preparation of the composition of the refractory concrete, the humidity of the aggregates (sand and gravel) must be previously measured in order to be able, if necessary, to adjust or correct the dosage of the final composition by redosing the aggregates and the water in the mixture. The humidity of the aggregates is determined by burning aggregates or hygrometric scales of a previous sample.

If any of the lightweight aggregate fractions, that is, if the fine fraction or the coarse fraction have moisture, the excess thereof must be subtracted from the total amount of water necessary to obtain the adequate dosage. If both fractions have moisture, the sum of both must be subtracted from the total amount of water necessary to obtain the adequate composition. This subtracted quantity of water must be replaced by more arid in the same quantity, fine or coarse respectively, until the desired quantity of water and arid is obtained. 
After this, the fabrication methodology is as follows:

(a) measure the moisture of the lightweight aggregate and adjust the amount of water and aggregate with respect to the final composition;

(b) adding, in the order described (the water, the superplasticizer additive, the cement and the fly ash to a mixing device);

(c) adding the fine aggregate or sand to the mixture obtained in (b); and

(d) adding the coarse aggregate or gravel to the mixture obtained in (c).

The mixing device is selected from a vertical axis planetary mixer or a concrete mixer, a concrete mixer truck and a concrete plant. The values of compressive strength, tensile strength and thermal conductivity were validated according to standardized tests:

- Regarding the characterization in fresh state of the refractory concrete, the settlement test or slump Abrams cone test is carried out, according to the specifications of the UNE EN 12350-2:2006 standard [26]. This test is used to determine the consistency of the mixture at the time of pouring the concrete. It also checks the homogeneity of the concrete through the segregation of the mixture.

- Regarding the characterization in the hardened state of the refractory concrete, tests of resistance to compression of cylindrical specimens are carried out, according to the UNE 12390-3:2001 standard [27].

- Indirect traction resistance tests are also carried out on cylindrical specimens UNE 12390-6:2010 [28] as well as thermal conductivity. For thermal conductivity tests, conductivity measurements are made both at room temperature (method A) according to the application of the UNE EN 12667:2002 standard [29], and at $150{ }^{\circ} \mathrm{C}$ and $250{ }^{\circ} \mathrm{C}$ (method B).

\subsubsection{High-Performance Concrete Fabrication}

For the fabrication of this concrete, all solid components, including cement, are initially incorporated into the concrete mixer device. Then half the water is added and, after two minutes of kneading, the rest of the water is incorporated together with the superplasticizer. Finally, the global mixture is kneaded for at least $15 \mathrm{~min}$ before it is poured on site. The mixing device is selected from a vertical axis planetary mixer or a concrete mixer, a concrete mixer truck and a concrete plant.

When the concrete arrives at the construction site, the self-compacting tests established by the Spanish EHE regulations [9] are carried out before pouring it into the tank. The tests performed are as follows:

- Slump flow test, according to UNE-EN 12350-8:2020 [30]

- V-shaped funnel test, according to UNE-EN 12350-9:2011 [31]

- $\quad$ L-box method, according to UNE-EN 12350-10:2011 [32]

- Slum flow J-ring test, according to UNE-EN 12350-12:2011 [33]

The compressive strengths were also determined at 7 and 28 days for the concrete manufactured for the construction site, according to UNE-EN 12390-3:2001 [27]. In some mixes, additionally, the indirect tensile strength (Brazilian test) was also tested according to UNE-EN 12390-6:2010 [28], using cylindrical specimens of $15 \times 30 \mathrm{~cm}$ for all these processes.

\subsection{Analytical Methods}

For the dosage development, several dosage methods are analyzed and followed: the Okamura method [34], the solids suspension method from Laboratoire Central des Ponts et Chaussées (LCPC) [35], the CBI method [36,37], the Domone method [38,39], the UPC method [40], the ACI method [41], the Larrard method [35], and the Mehta \& Aitcin method [11]. For testing, the methods presented in Table 6 were used.

Concrete workability was generally evaluated by the means of the slump cone test with the Abrams cone, which measures mixture workability, but this method is not appropriate to evaluate self-compacting behavior. Many tests were proposed for self-compacting evaluation, although the Spanish technical standard only lists the slump flow test (UNE- 
EN 12350-8:2011 [30]), the V-shaped funnel test (UNE-EN 12350-9:2011 [31]), the L-box method test (UNE-EN 12350-10:2011 [32]), and the slump flow test with J-ring (UNE-EN 12350-12:2011 [33]).

Table 6. Methods used for the characterization of the concrete formulations.

\begin{tabular}{cc}
\hline Parameter & Test Standard \\
\hline Compressive strength at 28 days & UNE-EN 12390-3:2001 Cylindrical samples 10 $\times 20 \mathrm{~cm} \mathrm{[27]}$ \\
Compressive strength at 56 days & UNE-EN 12390-3:2001 Cylindrical samples 10 $\times 20 \mathrm{~cm} \mathrm{[27]}$ \\
Compressive strength at 90 days & UNE-EN 12390-3:2001 Cylindrical samples $10 \times 20 \mathrm{~cm}$ [27] \\
Compressive strength after thermal treatment * & UNE-EN 12390-3:2001 Cylindrical samples 10 $\times 20 \mathrm{~cm} \mathrm{[27]}$ \\
Young modulus at 56 days & UNE-83316:1996 [42] corresponding to UNE-EN 13412:2008 Method 2 [43] \\
Young modulus at 56 days after thermal treatment * & UNE-83316:1996 [42] corresponding to UNE-EN 13412:2008 Method 2 [43] \\
Indirect tensile strength & UNE-EN 12390-6:2010 [28] \\
Indirect tensile strength after thermal treatment * & UNE-EN 12390-6:2010 [28] \\
Thermal conductivity & UNE-EN 12667:2002 [29] \\
Thermal conductivity with temperature (hot value) & Non-standard experimental test* \\
Density at hardened conditions & UNE-EN 12390-7:2001 [44] \\
Pervious porosity & ASTM C-642/06 [45] \\
Permanent dimensional variation & UNE-EN 993-10 [46] \\
Pervious porosity after thermal treatment * & ASTM C-642/06 [45]
\end{tabular}

$\left({ }^{*}\right)$ Experimental method: measurement of heat flux between two points on opposite sides of the concrete cubic sample, monitored with thermocouples and a thermo-flux plate. Cubic sample works as a closure element of a lab furnace which supplies heat to one of the sample sides.

Finally, standard methods and tests established by EHE [9] were followed for the characterization and evaluation of concrete. On the other hand, and similarly to highstrength self-compacting concrete, mechanical strength is evaluated via UNE-EN 123903:2001 method [27].

\subsection{Scaling-Up Concrete Preparation}

Heterogeneity in concrete properties is a widely known challenge, especially when it comes to specific requirements such as those evaluated here. For the same concrete mixture, it is likely to find compressive strength results that differ by more than $10 \%$ [47], even in the same quality control laboratory. This fact, extrapolated to different mixtures and laboratories, can lead to large variations even using the same equipment under the same atmospheric conditions.

Laboratory conditions are typically well-controlled [12]. However, once a concrete formulation is developed and characterized, a dosage validation at large-scale on-field is needed, which means ambient conditions, site equipment, and higher volumes of concrete. This integration for construction implies concrete fabrication in trucks after automatic dosage of cement and water, and manual dosage of the rest of the components (aggregates, additions and admixtures). Scaling up increased the volume of the trucks (from $2 \mathrm{~m}^{3}$ to $6 \mathrm{~m}^{3}$ ) under variable weather conditions, in order to characterize property variability in the future when the technology is implemented in different geographies.

The fabrication of six batches of the above presented mixture of concrete were prepared with the equipment planned for on-site works (truck mixer, automatized concrete plant for cement and water dosage and mobile crane for the rest of the components). Workability tests at different times are made for every single mixture and three specimens are taken from each concrete mixture fabricated for the compressive strength test. During these tests, the main conclusions and the final results were an on-field fabrication procedure and the reference formulation.

For high-strength self-compacting concrete the fabrication procedure was as follows:

1. Measurement of aggregates moisture to monitor actual $w / c$ ratio.

2. Correction of dosage searching for the referent $w / c$ ratio, in each case, for the concrete volume required. 
3. Addition of aggregates (fine and coarse fractions), discarding first quantities from hopper due to excessive moisture at the bottom of said element.

4. Addition of fibers and fines.

5. Weighing $2 / 3$ of water quantity to add to the retarder admixtures, reserving the remaining $33.33 \%$ to add later.

6. Addition of cement.

7. Addition of the remaining $1 / 3$ of water with the super-plasticizer additive

8. Mix for several minutes and visual inspection.

9. Transfer to construction site with truck hopper beating at maximum power (expected workability time 50 to $60 \mathrm{~min}$ ).

10. In case of non-self-compacting mixture on construction site, one re-dosage is allowed with a mix of $10 \mathrm{~L}$ of water with $1 \mathrm{~L}$ of super-plasticizer (additive supplier suggestion based on similar experiences on-field).

For insulating refractory concrete, the fabrication procedure is as follows:

1. Measurement of aggregates moisture to monitor actual $w / c$ ratio.

2. Correction of dosage searching for the referent $w / c$ ratio, in each case, for the concrete volume required.

3. After correction, weighing $90 \%$ of water quantity and reserving the remaining $10 \%$ to add at the end.

4. Addition of super-plasticizer.

5. Addition of cement and additional components at the same time to save pouring time (adding directly to the truck).

6. Addition of fine aggregates fraction.

7. Ascending movement of charging truck hopper three times to observe mixture and pull remainder material of hopper surfaces, at maximum speed (for $10 \mathrm{~min}$ ). Mixture should have fluid appearance but be viscous.

8. Addition of coarse aggregates fraction.

9. Mix for several minutes.

10. Realization of workability test. Expected consistency is soft. If Abrams cone measured is lower, ration water in $20 \mathrm{~kg}$-units until the effective $w / \mathrm{c}$ ratio searched, checking that workability is that which is required.

11. Transfer to construction site with truck hopper beating at maximum power (expected workability time 30 to $40 \mathrm{~min}$ ).

\subsection{Insulating Refractory Concrete Thermal Cycling}

The behavior of the insulating refractory concrete after thermal cycling is analyzed. The mechanical characteristics are based on the following tests after prolonged aging: (a) compressive strength (MPa), (b) Young Modulus (GPa) variation, (c) thermal conductivity, and (d) dimensional/thermal expansion variation due to heat exposure. Samples of different geometries were aged in a furnace following a representative cycle for practical commercial operation described in Figure 7: (a) isotherm at $215^{\circ} \mathrm{C}$ for $12 \mathrm{~h}$ and $20 \mathrm{~min}$, (b) heating at $66{ }^{\circ} \mathrm{C} / \mathrm{h}$ until $325{ }^{\circ} \mathrm{C}$, (c) isotherm at $325^{\circ} \mathrm{C}$ for $5 \mathrm{~h} 50 \mathrm{~min}$, (d) cooling at $69^{\circ} \mathrm{C} / \mathrm{h}$ until $222{ }^{\circ} \mathrm{C}$, (e) isotherm at $222^{\circ} \mathrm{C}$ for $2 \mathrm{~h} 20 \mathrm{~min}$. The test duration is 100 cycles (equivalent to 100 days of aging approximately, according to UNE-EN 12390-3:2001 [27]).

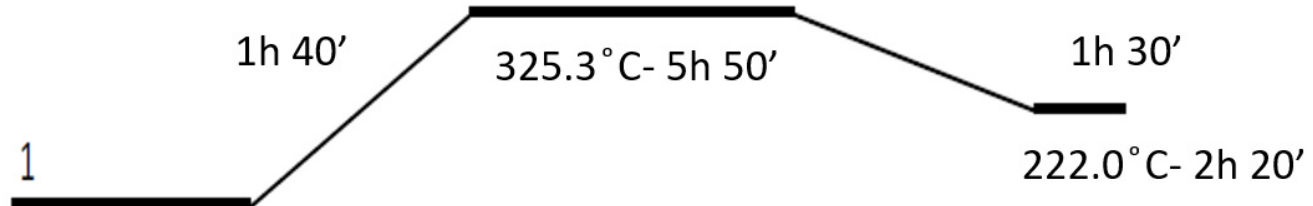

Figure 7. Thermal cycle for sample aging. 
Compression strength tests were performed on the aged samples according to standard UNE-EN 12390-4 [48]. The maximum load reached by the samples is recorded until rupture and the compressive strength of the concrete is calculated. The compressive strength of three thermally cycled 100x200 cm cylindrical samples was determined with a loading rate of $0.5 \pm 0.2 \mathrm{~N} / \mathrm{mm}^{2}$ per second.

The modulus of elasticity (Young modulus) is determined in accordance with the UNE-83316:1996 standard [42] and is established by measuring the strain variation of the loaded sample. The applied load rate is $0.5 \pm 0.2 \mathrm{~N} / \mathrm{mm}^{2}$ per second. The final stress applied in the test ( $\sigma \mathrm{a})$ corresponds to $1 / 3$ of the initially obtained compressive strength (fc/3). Load-unload cycles are carried out (minimum of three cycles) and the deformations are measured in three locations of the samples.

The thermal conductivity of the thermally cycled refractory concrete is measured according to standard UNE-EN 12664:2002 [49]. Three concrete sheet samples of $30 \times 30 \times 5 \mathrm{~cm}$ were obtained and kept at $20 \pm 1^{\circ} \mathrm{C}$ and $50 \%$ relative humidity during the three days prior to the conductivity measurements. The samples are conditioned then in a furnace at $105^{\circ} \mathrm{C}$ until steady state is reached (no mass change).

\section{Results and Discussion}

4.1. Results of Lab Tests

\subsubsection{High-Strength Self-Compacting Concrete Development}

Generally, high-strength self-compacting concretes (HSSCC) are made of the same materials used in conventional concretes, with the exception of the use of super-plasticizer admixtures, highest resistant category cements, and the addition of pozzolanic materials of high activity. The main difference is the individual component dosages. Most relevant characteristics of component materials are:

- Cement: For its use in HSSCC, cement must have an adjusted composition and fine grains, presenting high strength and, in turn, allowing good mixture workability. Cement fine size can be adjusted through grinding. The high specific surface area reached through the grinding process also benefits concrete self-compacting. Specifically, Portland CEM I cement of the highest resistant category (52.5 R) is appropriate, as well as any cement with high resistance additions, such as silica fume.

- $\quad$ Aggregates: In HSSCC fabrication the selection of aggregates must be more rigorous than in conventional concretes focusing on their good adherence with cement paste and their mechanical strength, which must exceed the target strength of the concrete to be formulated. Coarse aggregate tends to be smaller than conventional concrete aggregates, generally lower than $20 \mathrm{~mm}$; thus, a better flowability, better particles cohesion and higher strength are reached. Regarding fine aggregates, there is almost an absence of fines, which is solved by the large quantity of cement and additives [41].

- Filler: The employment of mineral filler allows the workability of the concrete mixture, especially needed in self-compacting HSSCC [50]. Mineral fillers, which are fine particles whose largest part passes through a $63 \mu \mathrm{m}$ sieve during sifting, can be considered as aggregates since they are obtained by grinding the same aggregate materials. Their selection must be made paying attention to their grading distribution, assuring compatibility with the rest of the concrete components by means of trial batches.

- Additives: In HSSCC it is indispensable to use fine additives, normally those with strong pozzolanic effect, due to two main reasons: (i) they add fines to get a good self-compacting behavior and (ii) they react with the resultant portlandite from cement hydration contributing to an important increase in concrete strength. Therefore, it is essential that additions present elevated fineness, high activity, great compatibility with other components and uniformity in their production [51]. Some facilitate selfcompacting property due to their spherical shape, optimizing the packing of solid particles during fresh state, and helping improve the concrete strength by reacting with portlandite (pozzolanic reaction from cement hydration) [10,52] like fly ashes. 
Silica fume, or micro silica, is a by-product obtained from electric arc furnaces of silicon production and ferro-silicon alloys fabrication. It is composed of 90-95\% amorphous silicon $\left(\mathrm{SiO}_{2}\right)$ and other minority components $\left(\mathrm{Fe}_{2} \mathrm{O}_{3}, \mathrm{CaO}, \mathrm{MgO}\right.$, etc. $)$. Silica fume particles have a large specific surface (around $20 \mathrm{~m}^{2} / \mathrm{g}$ ) [10]. Adding silica fumes requires high water quantity due to its elevated specific surface area, but it adds improvements to fresh concrete properties such as decreasing segregation and exudation. Similarly to fly ashes, but more intensively, it contributes to a concrete strength increase due to its nature and a filler effect derived from its elevated specific surface, creating a paste-aggregate transition zone more compact than concretes without this type of addition [11]. Metakaolin is another pozzolanic material obtained by kaolinite calcination and it is mainly composed of silica $\left(\mathrm{SiO}_{2}\right)$ and alumina $\left(\mathrm{Al}_{2} \mathrm{O}_{3}\right)$, although it also has other minority oxides such as $\mathrm{Fe}_{2} \mathrm{O}_{3}, \mathrm{CaO}$ or $\mathrm{MgO}$. Once again due to its pozzolanic reactivity and filler effect, metakaolin facilitates concrete elevated strengths. It also adds a higher durability by increasing concrete sulphate resistance and by complicating chloride diffusion, because concrete capillary porosity decreases [37].

- Fibers: Fibers are elements of short length and small section added to concrete. They can be classified according to their function in two large groups: (i) structural function, by providing post-cracking resistance to bulk concrete, and (ii) non-structural function, although improving concrete behavior against fire, shrink, wear, impact, etc. In the development of this high-strength concrete, polypropylene concrete fibers with nonstructural function are used.

- Admixtures: Substances added in small quantities into concretes (less than 5\% regarding cement mass) to modify properties, characteristics or behaviors [9]. These are chemical formulations, essential to obtain high-performance concretes. Superplasticizers are the main used admixtures for HSSCC. However, there are other admixtures that can be used to complement super-plasticizers, such as viscosity modulators, setting retardant, etc. Super-plasticizers allow large reductions of water quantity in the mixture without losing concrete flowability. In the past, the most commonly used super-plasticizers were melanin or naphthalene sulfonate and modified lignosulphonates, although nowadays the most common are based on polycarboxylate chains. These types of substance disperse cement particles, avoiding their flocculation since they are adsorbed over cement grains. By repulsive electrostatic interactions they unlock occluded water, making it available for fluidizing mix fine grains, increasing the workability of concrete. In addition to these interactions, polycarboxylate admixtures also apply a steric effect keeping separated cement grains with more efficiency and allowing enormous reductions in water dosage [11]. It is important to check compatibility between super-plasticizers, cement and selected fines, above all when the objective is to obtain low water/concrete $(w / c)$ ratios, due to possible segregation problems or setting alterations. Retarder admixtures increase concrete setting and/or hardening times, complicating at least at an initial stage the hydration of anhydrous components of cement. Their chemical composition is very variable, with sugars, lignosulphonates, zinc salts, borates, etc. [39]. They can act in two different ways, depending on their nature: (i) by facilitating calcium sulphate solubility that is a natural setting retarder, or (ii) by forming calcium salts to cover cement particles surfaces, thus retarding their hydration. Their use is convenient when cement quickly hydrates, because of its own nature or elevated temperature or due to the use of efficient super-plasticizers, being incompatible with construction requirements.

The high-strength concrete developed exceeds $100 \mathrm{MPa}$ compressive strength, reaching self-compacting properties with conventional component materials such as ordinary Portland cement, natural aggregates, simple additions and commercial admixtures, in order to arrive at a competitive cost, much lower than similar commercial concretes. The composition of a self-compacting concrete with high compressive strength is included in the patent WO 2015/055878 A1 [53] and it is detailed in Table 7. 
Table 7. High-strength concrete formulation [53].

\begin{tabular}{cc}
\hline Material & Quantity * \\
\hline Aggregate & $900-3000 \mathrm{~kg} / \mathrm{m}^{3}$ \\
Cement & $300-800 \mathrm{~kg} / \mathrm{m}^{3}$ \\
Water & $90-200 \mathrm{~kg} / \mathrm{m}^{3}$ \\
Fly ash & $40-150 \mathrm{~kg} / \mathrm{m}^{3}$ \\
Filler & $15-80 \mathrm{~kg} / \mathrm{m}^{3}$ \\
Silica fume & $40-80 \mathrm{~kg} / \mathrm{m}^{3}$ \\
Metakaolin & $40-80 \mathrm{~kg} / \mathrm{m}^{3}$ \\
Active dispersing agent & $10-20 \mathrm{~kg} / \mathrm{m}^{3}$ \\
Polypropylene fibers & $0,1 \mathrm{or} 2 \mathrm{~kg} / \mathrm{m}^{3}$ \\
\hline
\end{tabular}

* The Dreux-Gorisse method [54] is one technique among others that allows determining the proportions of the various constituents (sand, cement, gravel, water) of the concrete, starting with a granulometric analysis.

The detailed formulation of the high-strength self-compacting concrete developed in the laboratory is presented in Table 8. Results of the characterization of these tests are shown in Table 9, where the slum test shows the good workability achieved; compressive strength results were $112.5 \mathrm{MPa}$.

Table 8. Formulation of high-strength self-compacting concrete for lab tests.

\begin{tabular}{ccccc}
\hline & Material & Test 1 & Test 2 & Test 3 \\
\hline Cement & CEM I 52.5R/SR & $500 \mathrm{~kg}$ & $500 \mathrm{~kg}$ & $500 \mathrm{~kg}$ \\
Water & - & $160 \mathrm{~L}$ & $160 \mathrm{~L}$ & $160 \mathrm{~L}$ \\
Silica fume & Sika Fume S-92.D & $55 \mathrm{~kg}$ & $55 \mathrm{~kg}$ & $55 \mathrm{~kg}$ \\
Fly ash & - & $100 \mathrm{~kg}$ & $100 \mathrm{~kg}$ & $100 \mathrm{~kg}$ \\
Metakaolin & - & $55 \mathrm{~kg}$ & $55 \mathrm{~kg}$ & $55 \mathrm{~kg}$ \\
Filler & - & $30 \mathrm{~kg}$ & $30 \mathrm{~kg}$ & $30 \mathrm{~kg}$ \\
Aggregate 0/4 & - & $788 \mathrm{~kg}$ & $788 \mathrm{~kg}$ & $788 \mathrm{~kg}$ \\
Aggregate 2/8 & - & $926 \mathrm{~kg}$ & $926 \mathrm{~kg}$ & $926 \mathrm{~kg}$ \\
Superplasticizer & Sika Viscocrete-20 HE & $12.5 \mathrm{~kg}$ & $12.5 \mathrm{~kg}$ & $13.5 \mathrm{~kg}$ \\
Retardant & Sika Retarder 50 & $2.5 \mathrm{~kg}$ & $5.0 \mathrm{~kg}$ & $5.0 \mathrm{~kg}$ \\
Polypropylene fibers & Sika Fiber M-12 & $0.6 \mathrm{~kg}$ & $0.6 \mathrm{~kg}$ & $0.6 \mathrm{~kg}$ \\
\hline
\end{tabular}

Table 9. Results of high-strength self-compacting concrete for lab tests.

\begin{tabular}{cccc}
\hline Property & Test $\mathbf{1}$ & Test $\mathbf{2}$ & Test 3 \\
\hline Slum-test & $670 \mathrm{~mm}$ & $630 \mathrm{~mm}$ & $695 \mathrm{~mm}$ \\
Compression strength at 7 days & $111.5 \mathrm{MPa}$ & $105.5 \mathrm{MPa}$ & - \\
Compression strength at 28 days & $112.5 \mathrm{MPa}$ & $112.5 \mathrm{MPa}$ & - \\
\hline
\end{tabular}

\subsubsection{Insulating Refractory Concrete Development}

The new insulating refractory concrete requires stricter thermo-mechanical characteristics. Two key properties are evaluated: thermal resistance (expressed as the inverse of thermal conductivity) and mechanical strength.

Concrete thermal resistance is closely linked to density, specifically hardened concrete density, since internal porosity develops the main insulating function due to occluded air in matrix voids [13]. This porosity, and therefore density, can be reached only by means of two concrete components: aggregates and admixtures. However, to reduce costs, the aggregate type and dosage will limit the insulating nature and thermal resistance reached.

The concrete thermal resistance, depends on three main factors: (i) binder type, (ii) aggregate type, closely linked to the insulating function that determines material thermal conductivity, and (iii) total water/concrete $(w / c)$ ratio [40], along with mechanical strength, which is also closely linked to concrete density. In this case, the influence of the type of binder (cement material) is stronger than for thermal resistance, followed by that of type of aggregate, and effective $w / c$ ratio [55]. 
Two parameters influence the achievement of light weight with insulating properties: the effective and the total/theoretical $w / c$ ratio [56]. When aggregates (dry or wet not saturated) absorb water from the quantity added in the truck mixer, the available water is reduced, and the effective $w / c$ ratio will be lower than the theoretical ratio. In the development of this concrete, moist, non-saturated aggregates were used, therefore water absorption by aggregates caused a reduction in the effective water reacting with the cement. The dosage adjustment was based on this effective ratio. It is very important to determine the water absorbed by the aggregates (by the difference of the instantaneous aggregates moisture and their absorption index). It is also important to determine the difference from the total water of the dosage that will result in the effective level of water to combine with the cement. The decrease of concrete cohesion, due to the use of a higher $w / c$ ratio, causes a decrease of compressive strength. Therefore, the fabrication procedure established in this study considers these aspects, incorporating moisture measurements on field of the aggregates and formulation changes by adjusting the effective $w / c$ ratio.

For the selection of cement, two options are evaluated for the temperatures required $\left(>300^{\circ} \mathrm{C}\right)$ : ordinary Portland cements or high alumina cement. Portland cements, in their I-52.5R or I-42.5R types, are low cost and allow the use of additives to reduce hydration heat and, in parallel, to increase mechanical strength, taking into advantage the pozzolanic reaction [56]. On the other hand, their thermal behavior is poor. However, the high alumina cements provide a complete thermal resistance and stability because usual operation exceeds $1000^{\circ} \mathrm{C}$, but unfortunately their high cost would make the TES system unfeasible, due to the increase of at least $500 \%$ of the final refractory cost. Besides, high alumina concrete has an elevated hydration heat and its mechanical strength could decrease with time $[57,58]$, which would compromise structural stability if previous drying and thermal treatment is made.

High porosity aggregates are selected to provide enough thermal resistance (insulating) capacity. Two kinds of lightweight aggregates, with low density and high porosity, were considered as candidates from most of the current standard and commercial options to achieve a competitive cost: pumice stone (in four grading distributions, PP from Italy and PPP from Puertollano, Spain) and expanded clay (in three grading distributions, AE). The reference used for this pre-selection is taken from the data catalogue of Constructive Elements of CTE (Código Técnico de la Edificación) [59] which lists concrete density and thermal conductivity values for different types of aggregates, as shown in Table 10. Experimentally, the following grading distributions were analyzed: $0 / 4$ and 6/12 for PP; $0 / 4$, 4/8, and 10/20 for PPP; and 0/4,3/10 and 8/16 for AE, obtaining density values much lower for the expanded clay (which is selected), directly influenced by its high porosity, inherent to its calcination fabrication procedure [60].

Table 10. Properties of concrete for different aggregates used [59].

\begin{tabular}{ccc}
\hline Material & Density $\left[\mathrm{kg} / \mathrm{m}^{3}\right]$ & Thermal Conductivity $[\mathrm{W} / \mathrm{m} \cdot \mathbf{K}]$ \\
\hline Pre-manufacturing concrete & 1600 & $0.69-0.88$ \\
Concrete with pumice stone & 1300 & $0.38-0.41$ \\
Concrete with expanded clay & 1200 & $0.39-0.41$ \\
\hline
\end{tabular}

The rest of the components were selected to ensure the target mechanical strength and concrete workability. The workability was assessed by reaching a soft or fluid concrete by means of the Abrams cone workability test. The achievement of an additional increase of resistance implied the use of fine additions, which helped cement binding power and complements aggregate fine fractions. Factors that determine reaching a fluid or soft consistency were: (i) fines content (additions), (ii) use of admixtures and interaction with cement (plasticizers or super-plasticizers that improve flowability without affecting mechanical parameters), (iii) water content, and (iv) aggregates morphology (use of expanded clays facilitates concrete mass homogeneity). Water content represented the most critical factor 
because it leads to a huge variability in concrete property results. Tested additives in this study were fly ashes and silica fume, while super-plasticizer was tested for admixtures.

This concrete formulation study began by the combination of the selected components, from mortar dosages until reaching concrete character with coarse aggregates. The main difference in approach compared to the HSSCC development was the combined mechanicalinsulating resistance for the refractory wall, unusual in concrete formulations. Therefore, the work scheme is the following:

1. Target density achievement: fresh state, hardened state after $24 \mathrm{~h}$, hardened state at different ages, hardened state of dry simple $\left(24 \mathrm{~h}, 45^{\circ} \mathrm{C}\right)$, and hardened state after thermal ageing at $300{ }^{\circ} \mathrm{C}$.

2. Thermal resistance assessment.

3. Compressive strength assessment.

4. Behavior assessment after thermal ageing.

5. Conclusions, feedback, and formulation modification.

To sum up, the insulating refractory concrete to be developed must exceed conventional values of compressive strength (20-25 MPa in ordinary concretes for structural purposes) and workability (soft or fluid type, more than $6 \mathrm{~cm}$ of cone slump), reaching insulating properties by developing a thermal conductivity lower than $0.4 \mathrm{~W} / \mathrm{m} \cdot \mathrm{K}$. Above all, conventional components materials such as ordinary Portland cement (not the typical high alumina cement in refractories products), lightweight aggregates, simple additions and commercial admixtures were necessary in order to get a competitive cost, much lower than similar commercial concretes at the temperature level indicated.

The composition of the refractory concrete with low conductivity is included in the patent WO 2015/055879 A1 [61] and is detailed in Table 11.

Table 11. Insulation refractory concrete formulation [61].

\begin{tabular}{cc}
\hline Material & Quantity * \\
\hline Light aggregate & $500-850 \mathrm{~kg} / \mathrm{m}^{3}$ \\
Cement & $400-700 \mathrm{~kg} / \mathrm{m}^{3}$ \\
Water & $100-350 \mathrm{~kg} / \mathrm{m}^{3}$ \\
Fly ash & $50-200 \mathrm{~kg} / \mathrm{m}^{3}$ \\
Active dispersing agent & $2-10 \mathrm{~kg} / \mathrm{m}^{3}$ \\
Ration $w / c$ & $0.45-0.75$ \\
\hline
\end{tabular}

* The Dreux-Gorisse method [54] is one technique among others that allows the determination of the proportions of the various constituents (sand, cement, gravel, water) of the concrete, starting with a granulometric analysis.

Detailed formulation on the insulating refractory concrete developed in the laboratory is presented in Table 12. Results of the characterization of these tests are shown in Table 13, where adequate consistency was achieved, with a compressive strength higher than the required $25 \mathrm{MPa}$, and with a thermal conductivity of $0.32-0.33 \mathrm{~W} / \mathrm{m} \cdot \mathrm{K}$, again lower than that required $(0.4 \mathrm{~W} / \mathrm{m} \cdot \mathrm{K})$.

Table 12. Formulation of insulating refractory concrete for lab tests.

\begin{tabular}{cccccccc}
\hline & Material & Test 1 & Test 2 & Test 3 & Test 4 & Test 5 & Test 6 \\
\hline Cement & CEM I-52,5R & $461 \mathrm{~kg}$ & $450 \mathrm{~kg}$ & $450 \mathrm{~kg}$ & $450 \mathrm{~kg}$ & $450 \mathrm{~kg}$ & $450 \mathrm{~kg}$ \\
Fly ash & - & $101 \mathrm{~kg}$ & $107 \mathrm{~kg}$ & $107 \mathrm{~kg}$ & $107 \mathrm{~kg}$ & $107 \mathrm{~kg}$ & $107 \mathrm{~kg}$ \\
Superplasticizer & Glenium C303 SCC & $4.66 \mathrm{~kg}$ & $4.55 \mathrm{~kg}$ & $4.55 \mathrm{~kg}$ & $4.55 \mathrm{~kg}$ & $4.55 \mathrm{~kg}$ & $4.55 \mathrm{~kg}$ \\
Sand & AE 0/4 Arlite & $506 \mathrm{~kg}$ & $494 \mathrm{~kg}$ & $494 \mathrm{~kg}$ & $494 \mathrm{~kg}$ & $494 \mathrm{~kg}$ & $494 \mathrm{~kg}$ \\
Gravel & AE 3/10 Arlite & $218 \mathrm{~kg}$ & $213 \mathrm{~kg}$ & $213 \mathrm{~kg}$ & $213 \mathrm{~kg}$ & $213 \mathrm{~kg}$ & $213 \mathrm{~kg}$ \\
Water & - & $196 \mathrm{~L}$ & $214 \mathrm{~L}$ & $214 \mathrm{~L}$ & $214 \mathrm{~L}$ & $214 \mathrm{~L}$ & $214 \mathrm{~L}$ \\
Relation $w / \mathrm{c}$ & - & 0.65 & 0.69 & 0.71 & 0.71 & 0.71 & 0.71 \\
\hline
\end{tabular}


Table 13. Results of insulating refractory concrete for lab tests.

\begin{tabular}{|c|c|c|c|c|c|c|}
\hline Property & Test 1 & Test 2 & Test 3 & Test 4 & Test 5 & Test 6 \\
\hline Consistency & $22 \mathrm{~cm}$ & $21 \mathrm{~cm}$ & $21 \mathrm{~cm}$ & $21 \mathrm{~cm}$ & $21 \mathrm{~cm}$ & $21 \mathrm{~cm}$ \\
\hline Compression strength at 7 days & $24 \mathrm{MPa}$ & $25 \mathrm{MPa}$ & $21 \mathrm{MPa}$ & $20 \mathrm{MPa}$ & $20 \mathrm{MPa}$ & $19 \mathrm{MPa}$ \\
\hline Compression strength at 28 days & $28.5 \mathrm{MPa}$ & $28.8 \mathrm{MPa}$ & $24.4 \mathrm{MPa}$ & $24.0 \mathrm{MPa}$ & $23.7 \mathrm{MPa}$ & $22.4 \mathrm{MPa}$ \\
\hline Thermal conductivity & \multicolumn{6}{|c|}{$0.32-0.33 \mathrm{~W} / \mathrm{m} \cdot \mathrm{K}$} \\
\hline
\end{tabular}

\subsection{Results of Scaling Up Tests}

\subsubsection{High-Strength Self-Compacting Concrete Fabrication}

A constructive large-scale sample $\left(50 \mathrm{~m}^{3}\right)$ of the high-strength self-compacting concrete was built to evaluate on-site properties. The ambient conditions during the tests were: $\mathrm{min} /$ max temperature $6.1-15.4^{\circ} \mathrm{C}$, average temperature $9.1^{\circ} \mathrm{C}, \mathrm{min} /$ max relative humidity $45.0-98.8 \%$, average relative humidity $75.5 \%$. Nine different concrete tests were prepared; results are presented below.

Due to the high influence of the moisture content in the materials used to produce the concrete mixtures, moisture measurements of sand and gravel were carried out. Table 14 shows that the sand samples had a moisture content of between $3.2 \%$ and $5.1 \%$, with a standard deviation of maximum $1.2 \%$, while gravel samples had a moisture content of between $0.95 \%$ and $1.7 \%$, with a maximum standard deviation of $0.2 \%$. It should be highlighted that the materials used in tests 8 and 9 were stored outdoors, therefore their moisture content is higher than most of the other samples.

Table 14. Moisture content of materials used to produce high-strength self-compacting concrete at pilot plant scale.

\begin{tabular}{ccccccccc}
\hline \multirow{2}{*}{ Test } & \multicolumn{3}{c}{ Sand 0/4 } & \multicolumn{4}{c}{ Gravel 2/8 } \\
\cline { 2 - 8 } & Test 1 & Test 2 & Average & St. Dev. & Test 1 & Test 2 & Average & St. Dev. \\
\hline 1 & 3.9 & 5.3 & 4.60 & 0.70 & 1.4 & 1.6 & 1.50 & 0.10 \\
2 & 4.4 & 3.5 & 3.95 & 0.45 & 1.0 & 1.0 & 1.00 & 0.00 \\
3 & 3.8 & 3.7 & 3.75 & 0.05 & 1.3 & 1.1 & 1.20 & 0.10 \\
4 & 2.9 & 3.7 & 3.30 & 0.40 & 0.8 & 1.4 & 1.10 & 0.30 \\
5 & 3.2 & 3.2 & 3.20 & 0.00 & 1.3 & 1.2 & 1.25 & 0.05 \\
6 & 3.5 & 3.7 & 3.60 & 0.10 & 1.0 & 0.9 & 0.95 & 0.05 \\
7 & 3.6 & 3.7 & 3.65 & 0.05 & 1.2 & 1.7 & 1.45 & 0.25 \\
8 & 4.3 & 4.3 & 4.30 & 0.00 & 1.6 & 1.5 & 1.55 & 0.05 \\
9 & 6.3 & 3.9 & 5.10 & 1.20 & 1.5 & 1.9 & 1.70 & 0.20 \\
\hline
\end{tabular}

To evaluate these nine samples a slump-flow test was performed (Table 15). Only test 1 and test 3 failed, having bad workability; in all other tests, the compaction was enough to achieve the appropriate mechanical properties. These problems seemed to come from null humidity in the dry additions used (silica fume, fly ash, metakaolin, and filler) as they are stored and prepared inside an industrial facility; this means water absorption is higher than initially expected. Figure 8 shows two examples of the slump-flow results in the tests carried out.

The relative compression strength results from the successful tests are shown in Figure 9. The results after 7 days are within $89 \%$ and $97 \%$ of the target value and after 28 days between $105 \%$ and $112 \%$ of the target value; therefore, the tests are considered successful.

Results show that the scaling up was successful, achieving appropriate mechanical properties when the moisture of the materials to be used is within expected values (too low moisture results in bad workability). Moreover, it was demonstrated that climate conditions (temperature and relative humidity) did not affect the concrete production. 
Table 15. Visual inspection and slum test results of the pilot plant scale high-strength self-compacting concrete production.

\begin{tabular}{|c|c|c|c|c|c|}
\hline \multirow{2}{*}{ Sample } & \multirow{2}{*}{ Visual Inspection } & \multicolumn{3}{|c|}{ Slump-Flow Test } & \multirow{2}{*}{ Test Accepted? } \\
\hline & & $\mathrm{T}_{50}(\mathrm{~s})$ & $D_{t}(\mathrm{~mm})$ & Evaluation & \\
\hline 1 & A little fluid & 11.90 & 560 & Failed & No \\
\hline 2 & $\begin{array}{c}\text { A little fluid and disaggregated } \\
\text { No segregation }\end{array}$ & 4.16 & 680 & Successful & Yes \\
\hline 3 & A little fluid & 9.00 & 635 & Failed & No \\
\hline 4 & $\begin{array}{c}\text { A little fluid and disaggregated } \\
\text { No segregation }\end{array}$ & 6.03 & 610 & $\begin{array}{c}\text { Successful } \\
\text { Need to compaction } \\
\text { by vibration }\end{array}$ & Yes \\
\hline 5 & $\begin{array}{c}\text { A little fluid and disaggregated } \\
\text { No segregation }\end{array}$ & 5.82 & 655 & $\begin{array}{c}\text { Successful } \\
\text { Need to compaction } \\
\text { by vibration }\end{array}$ & Yes \\
\hline 6 & $\begin{array}{l}\text { No segregation } \\
\text { Great aspect and homogeneity }\end{array}$ & 3.07 & 710 & Successful & Yes \\
\hline 7 & $\begin{array}{l}\text { No segregation } \\
\text { Great aspect and homogeneity }\end{array}$ & 5.88 & 655 & Successful & Yes \\
\hline 8 & Slight segregation & 4.90 & 610 & $\begin{array}{c}\text { Successful } \\
\text { Need of extra compaction }\end{array}$ & Yes \\
\hline 9 & $\begin{array}{l}\text { Visually disaggregated } \\
\text { No segregation }\end{array}$ & 3.72 & 650 & Successful & Yes \\
\hline
\end{tabular}

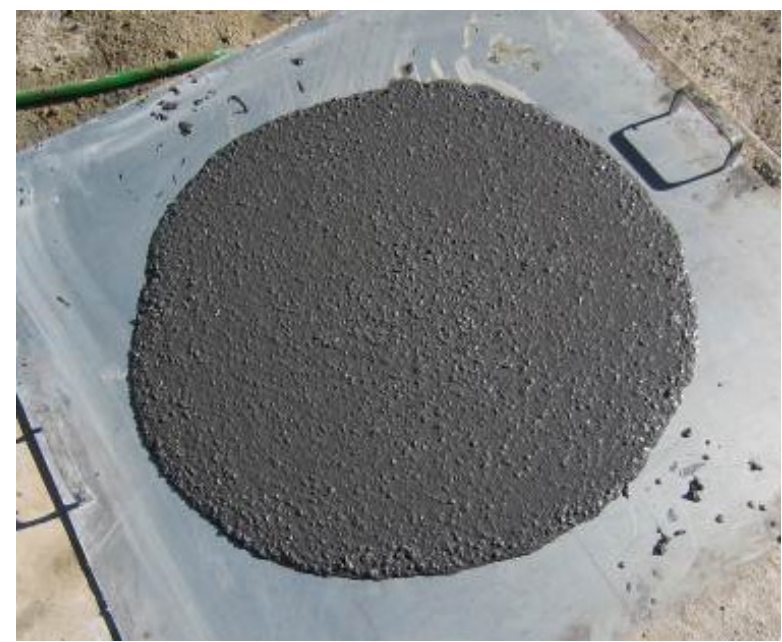

(a)

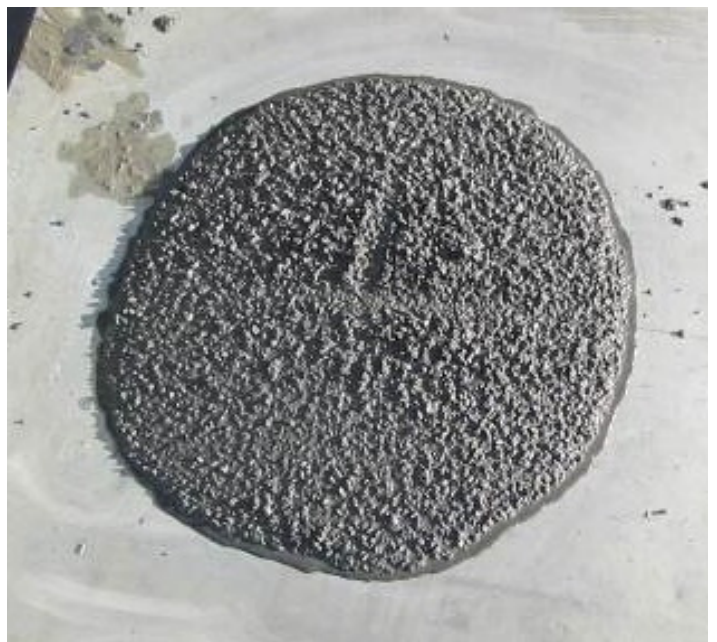

(b)

Figure 8. Slump-flow tests from (a) test 6 and (b) test 8 high-strength self-compacting concrete production.

\subsubsection{Insulating Refractory Concrete Fabrication}

The insulating refractory concrete was developed with the following ambient conditions: $\min / \max$ temperature $16.2-39.3{ }^{\circ} \mathrm{C}$, average temperature $27.4{ }^{\circ} \mathrm{C}, \mathrm{min} / \mathrm{max}$ relative humidity $16.9-83.5 \%$, average relative humidity $44.1 \%$. Eight different concrete tests were prepared and mixed in two trucks; the results are presented below.

The target value of workability is $22 \mathrm{~cm}$ for the Abrams cone, set to ensure later transfer from the concrete plant to the construction site, at $30 \mathrm{~min}$ distance. In this concrete, the gravel particles were immersed in water for one night to get saturation and ensure the absorption grade specified by the supplier $(24.10 \%)$. The moisture of the sand used in each test was measured, with results from $13 \%$ to $22 \%$. With these data and the results from the workability tests, the formulation of each concrete is adjusted to achieve the desired cone $(>22 \mathrm{~cm})$. 
Once on the construction site, the first mixture seems softer, almost plastic, but with a homogeneous and workable appearance. That is why the workability test is carried out again, obtaining a cone of $17 \mathrm{~cm}$ (loss of $5 \mathrm{~cm}$, typical value). Regarding the second mixture, consistency seems fluid and with a homogeneous and workable appearance, reaching cones of $20 \mathrm{~cm}$ (again coherent values of loss: $5 \mathrm{~cm}$ ).

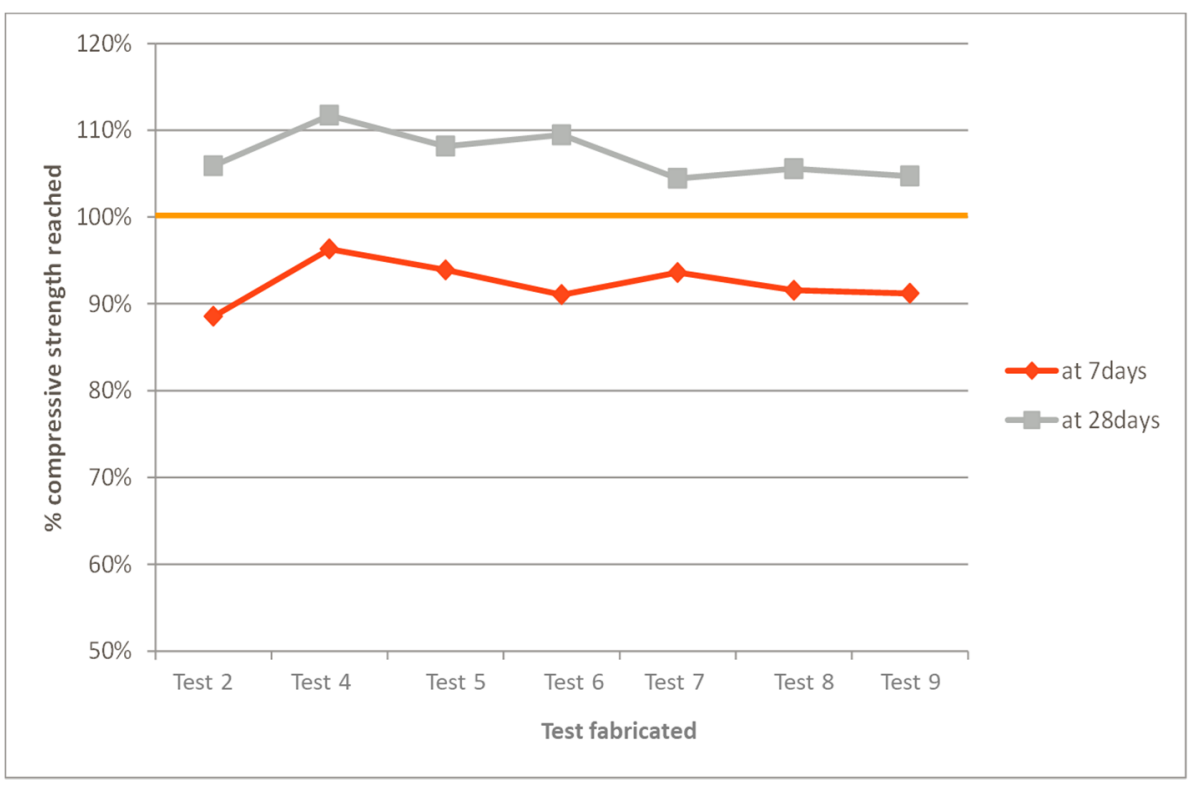

Figure 9. Relative compressive strength of the pilot plant scale high-strength self-compacting concrete tests.

The relative compression strength results after 1,7,28, and 90 days from the two truck concretes are shown in Figure 10. Results from the two truck tests are very similar, reaching the stated target after 90 days, but being at $92 \%-97 \%$ of the target already after 28 days.

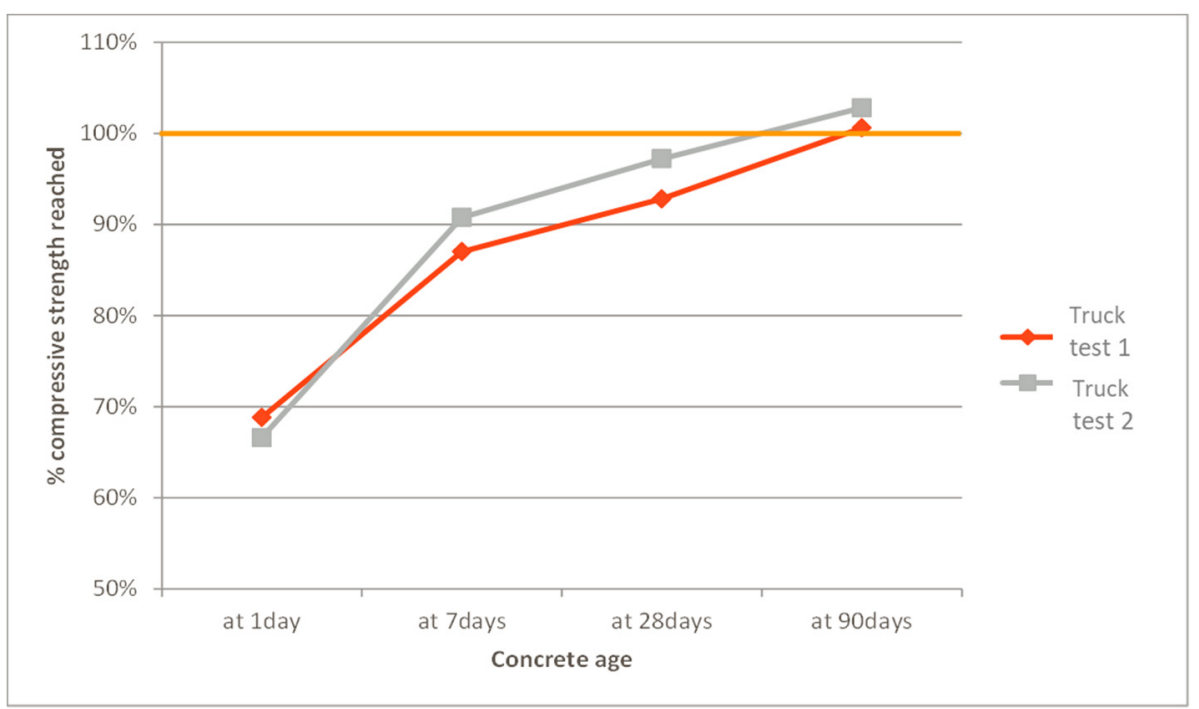

Figure 10. Relative compressive strength of the pilot plant scale insulating refractory concrete tests.

Results show that controlling the moisture of the materials is needed to obtain good workability and, for this concrete type, ambient temperature affects this workability. Good control of water content in the concrete mixture when performing cone tests ensures that the concrete produced achieves the desired mechanical properties. 


\subsubsection{Thermal Cycling of the Insulating Refractory Concrete}

The results of compression strength and Young modulus of the insulating refractory concrete after 100 thermal cycles are shown in Table 16. The compression strength decreased by $41 \%$ and the Young modulus by $60 \%$, making the validation of the results difficult.

Table 16. Compression strength test results and elastic modulus (Young modulus) of insulating refractory concrete cylindrical samples after 100 thermal cycles.

\begin{tabular}{|c|c|c|c|c|}
\hline Sample & $\begin{array}{l}\text { Compression } \\
\text { Strength (MPa) }\end{array}$ & $\begin{array}{l}\text { Variation from } \\
\text { Non-Cycled Concrete }\end{array}$ & $\begin{array}{c}\text { Young Modulus } \\
\text { E (GPa) }\end{array}$ & $\begin{array}{l}\text { Variation from } \\
\text { Non-Cycled Concrete }\end{array}$ \\
\hline $\begin{array}{l}\text { Cylindrical samples } \\
100 \times 200 \mathrm{~cm}\end{array}$ & $16.06+/-0.48$ & $-41 \%$ & 5.4 & $-60 \%$ \\
\hline
\end{tabular}

Table 17 shows that, even though the thermal conductivity of the insulating refractory concrete is lower than the commercial refractory concrete (Table 2), it remains almost constant after 100 thermal cycles.

Table 17. Thermal conductivity results of insulating refractory concrete cylindrical samples after 100 thermal cycles.

\begin{tabular}{ccc}
\hline Number of Cycles & Thermal Conductivity $\mathbf{( W / m \cdot K )}$ & Thermal Resistance (mK/W) \\
\hline 0 & 0.330 & - \\
100 & 0.276 & 0.0195 \\
\hline
\end{tabular}

\section{Conclusions}

A complete process of new materials development facing high thermo-mechanical requirements is carried out within a new technology developed by Abengoa, consisting in a cylindrical tank for thermal energy steam accumulation, composed of a double concrete wall made of an external wall of self-compacting high-strength concrete and an internal wall of insulating refractory concrete.

Components and dosages analysis are carried out from materials selection to concrete formulations, counting on essential tests for this application (workability, compressive strength, and thermal conductivity) until the proposal of definitive dosages, both patented by Abengoa Solar NT.

On-field tests are performed to verify and validate the process of concrete fabrication, implementing the established formulation and fabrication procedures developed during previous research activities. During all the fabrication tests as well as the concreting processes, it is determined and confirmed that, in special concretes like these, there are several external and internal factors that affect the material in a critical way and could modify the dosages initially defined.

The main conclusion from the development of the high-strength self-compacting concrete (HSSCC) is:

- The moisture of aggregates and additions is the main factor found during this concrete fabrication. This point is directly related to the storage conditions of the raw materials. It is shown that external storage could create an excess of moisture in the aggregates and additions that could cause changes in the hydration process of concrete fabrication. This fact triggers a dosage correction that might be inaccurate if, in following concreting processes, the storing conditions are different, when water absorption increases and, therefore, causes a drier concrete mix that does not meet the expected workability requirements.

The main conclusions from the development of this insulating refractory concrete are:

- Effective $w / c$ ratio is the key control parameter for the success of insulating refractory concrete fabrication, supported by workability tests with the Abrams cone method. 
A suitable and accurate previous determination, as well as a constant control during concrete fabrication, permits the achievement of the target resistance and thermal requirements. The success of this insulating refractory concrete is based on a referent effective $w / c$ ratio establishing limits for the fabrication process. Besides, workability verification presents value of $20 \mathrm{~cm}$ in the Abrams cone for acceptance of the concrete mixture transfer.

- Aggregates and their physical properties represent the second most important factor to rigorously control the properties of insulating refractory concrete. The selection of such special aggregate, expanded clay, determines that porosity and absorption grade are critical points to match specified requirements in all the mixtures fabricated. It is essential to previously control aggregate porosity and absorption in every batch, since grains absorb a fraction of the dosage water during fabrication, reducing the planned amount of water to be combined with the cementitious products. This fact has a negative effect if the dosage is not previously corrected, leading to structurally weak and non-uniform concrete.

- The instantaneous moisture of aggregates is identified as a key parameter. Dosage correction by the absorbed water is directly related to that parameter at the time the compounds are mixed. Due to very high absorption of the selected gravel, presaturation of gravel grains is prescribed so that dosage water is not absorbed by aggregates. Regarding sand, the formulation correction is applied by means of the previous measurement of moisture just before the charge of the other component materials. This factor is also linked to the first (effective $w / c$ ratio), creating a control parameter triangle which must be the axis around which concrete is fabricated: $w / c$, absorption grade and aggregates moisture.

- Finally, ambient temperature is confirmed as the external factor per excellence in concrete fabrication. Moreover, with such high temperatures during this research, this factor becomes critical. It is necessary to minimize temperature affection on concrete with measures such as: (i) previous saturation of aggregates, (ii) protection of mixture fabrication hoppers from direct radiation of sun and (iii) a quick and efficient transfer to construction site to maintain required workability.

The effect of thermal cycling on refractory insulating concrete is a decrease in the thermal conductivity (and therefore an increase in insulating effect), but also a reduction in the mechanical strength. After 100 thermal cycles, samples showed a $40 \%$ reduction in compressive strength and a $60 \%$ in Young Modulus' values when compared to reference concrete samples. In both types of concrete developed, strict control and monitoring of the concreting process are essential. As shown in this paper, workability problems could appear even though control is meticulous; the absence of this kind of control probably drives failure in the concreting process. For different reasons in each type of concrete developed, aggregates moisture, ambient temperature and $w / c$ ratio have arisen as the key factors for the success of these special materials in the newly designed steam accumulation tank.

Although very encouraging results were obtained in this study, further research is needed to corroborate the formulations, to carry out their scalability, and to perform tests at pilot plant scale.

Author Contributions: Conceptualization, C.P. and D.P.O.; methodology, C.P., E.G.-R. and L.F.C.; formal analysis, C.P., E.G.-R. and S.F.; investigation, E.G.-R. and D.P.O.; resources, C.P. and L.F.C.; data curation, D.P.O; writing-original draft preparation, C.P., S.F. and L.F.C.; writing-review and editing, D.P.O. and E.G.-R.; visualization, C.P. and L.F.C.; supervision, C.P. and L.F.C.; project administration, C.P.; funding acquisition, C.P. and L.F.C. All authors have read and agreed to the published version of the manuscript.

Funding: The research leading to these results has received funding from CDTI in the project Innterconecta Thesto (ITC-20111050). The work is partially funded by the Spanish government (ENE2015-64117-C5-1-R (MINECO/FEDER)). This work was partially funded by the Ministerio de Ciencia, Innovación y Universidades de España (RTI2018-093849-B-C31-MCIU/AEI/FEDER, UE) and by the Ministerio de Ciencia, Innovación y Universidades-Agencia Estatal de Investi- 
gación (AEI) (RED2018-102431-T). This work is partially supported by ICREA under the ICREA Academia programme.

Data Availability Statement: Data is available upon request to the corresponding authors.

Acknowledgments: The authors would like to thank all the Chirivo Construcciones, Hormigones Aznalcóllar, Elabora, Azcatec, Next Force Engineering, Universidad de Granada, Aidico, Centro Andaluz de Metrología, AICIA and Abengoa teams involved in Solúcar Platform during prototype construction and start-up. Cabeza would like to thank the Catalan Government for the quality accreditation given to her research group GREiA (2017 SGR 1537). GREiA is a certified agent TECNIO in the category of technology developers from the Government of Catalonia.

Conflicts of Interest: The authors declare no conflict of interest.

\section{References}

1. Liu, M.; Steven Tay, N.H.; Bell, S.; Belusko, M.; Jacob, R.; Will, G.; Saman, W.; Bruno, F. Review on concentrating solar power plants and new developments in high temperature thermal energy storage technologies. Renew. Sustain. Energy Rev. 2016, 53, 1411-1432. [CrossRef]

2. International Renewable Energy Agency (IRENA). Innovation Outlook: Thermal Energy Storage; International Renewable Energy Agency: Abu Dhabi, United Arab Emirates, 2020.

3. González-Roubaud, E.; Pérez-Osorio, D.; Prieto, C. Review of commercial thermal energy storage in concentrated solar power plants: Steam vs. molten salts. Renew. Sustain. Energy Rev. 2017, 80, 133-148. [CrossRef]

4. Pirvaram, A.; Sadrameli, S.M.; Abdolmaleki, L.; Sivaram, A.R.; Karuppasamy, K.; Rajavel, R. Review on phase change materials (PCMs) for cold thermal energy storage applications. Int. J. Refrig. 2017, 35, 984-991. [CrossRef]

5. Islam, M.T.; Huda, N.; Abdullah, A.B.; Saidur, R. A comprehensive review of state-of-the-art concentrating solar power (CSP) technologies: Current status and research trends. Renew. Sustain. Energy Rev. 2018, 91, 987-1018. [CrossRef]

6. Stekli, J.; Irwin, L.; Pitchumani, R. Technical Challenges and Opportunities for Concentrating Solar Power with Thermal Energy Storage. J. Therm. Sci. Eng. Appl. 2013, 5. [CrossRef]

7. Liu, J.; Kong, J.; Kong, X. Shaking table model tests of concrete containment vessel (CCV) for CPR1000 nuclear power plant. Prog. Nucl. Energy 2016, 93, 186-204. [CrossRef]

8. Afefy, H.M. Seismic Retrofitting of Reinforced-Concrete Coupled Shear Walls: A Review. Pract. Period Struct. Des. Constr. 2020, 25, 03120001. [CrossRef]

9. De Fomento, M. Instrucción de Hormigón Estructural; EHE-08 2008; Ministerio de Fomenta: Madrid, Spain, 2010.

10. Asociación Española de Hormigón Estructural. Monografía M-13 de Ache. In Hormigón Autocompactante: Diseño y Aplicación; Asociación Española de Hormigón Estructural: Madrid, Spain, 2018.

11. Aitcin, P. High Performance Concrete; CRC Press: London, UK, 1998; Volume 19980236, pp. 1-624. [CrossRef]

12. Moreno, D.; Zunino, F.; Paul, Á.; Lopez, M. High strength lightweight concrete (HSLC): Challenges when moving from the laboratory to the field. Constr. Build. Mater. 2014, 56, 44-52. [CrossRef]

13. Al-Jabri, K.S.; Hago, A.W.; Al-Nuaimi, A.S.; Al-Saidy, A.H. Concrete blocks for thermal insulation in hot climate. Cem. Concr. Res. 2005, 35, 1472-1479. [CrossRef]

14. Salas, J.; Alvarez, M.; Veras, J. Lightweight insulating concretes with rice husk. Int. J. Cem. Compos. Light Concr. 1986, 8, 171-180. [CrossRef]

15. Chabannes, M.; Bénézet, J.-C.; Clerc, L.; Garcia-Diaz, E. Use of raw rice husk as natural aggregate in a lightweight insulating concrete: An innovative application. Constr. Build. Mater. 2014, 70, 428-438. [CrossRef]

16. Liu, M.Y.J.; Alengaram, U.J.; Jumaat, M.Z.; Mo, K.H. Evaluation of thermal conductivity, mechanical and transport properties of lightweight aggregate foamed geopolymer concrete. Energy Build. 2014, 72, 238-245. [CrossRef]

17. Huiskes, D.M.A.; Keulen, A.; Yu, Q.L.; Brouwers, H.J.H. Design and performance evaluation of ultra-lightweight geopolymer concrete. Mater. Des. 2016, 89, 516-526. [CrossRef]

18. Chen, B.; Liu, N. A novel lightweight concrete-fabrication and its thermal and mechanical properties. Constr. Build. Mater. 2013, 44, 691-698. [CrossRef]

19. Yu, Q.L.; Spiesz, P.; Brouwers, H.J.H. Ultra-lightweight concrete: Conceptual design and performance evaluation. Cem. Concr. Compos. 2015, 61, 18-28. [CrossRef]

20. López, M.; Kahn, L.F. Hormigón liviano de alto desempeño-Una comparación entre pérdidas de pretensado reales y estimadas por los códigos de diseño. Rev. Ing. Construcción 2007, 22. [CrossRef]

21. Ke, Y.; Beaucour, A.L.; Ortola, S.; Dumontet, H.; Cabrillac, R. Influence of volume fraction and characteristics of lightweight aggregates on the mechanical properties of concrete. Constr. Build. Mater. 2009, 23, 2821-2828. [CrossRef]

22. Dhir, K.; Mays, R.G.C.; Chua, H.C. Lightweight structural concrete with Aglite aggregate: Mix design and properties. Int. J. Cem. Compos. Light Concr. 1984, 6, 249-261. [CrossRef]

23. Wilson, H.S.; Malhotra, V.M. Development of high strength lightweight concrete for structural applications. Int. J. Cem. Compos. Light Concr. 1988, 10, 79-90. [CrossRef] 
24. Kockal, N.U.; Ozturan, T. Effects of lightweight fly ash aggregate properties on the behavior of lightweight concretes. J. Hazard. Mater. 2010, 179, 954-965. [CrossRef] [PubMed]

25. Kockal, N.U.; Ozturan, T. Durability of lightweight concretes with lightweight fly ash aggregates. Constr. Build. Mater. 2011, 25, 1430-1438. [CrossRef]

26. Asociación Española de Normalización y Certificación (AENOR). Testing Fresh Concrete-Part 2: Slump Test 2006; UNE-EN 12350-2:2006; AENOR: Madrid, Spain, 2006.

27. Asociación Española de Normalización y Certificación (AENOR). Testing Hardened Concrete—Part 3: Compressive Strength of Test Specimens 2001; UNE 12390-3:2001; AENOR: Madrid, Spain, 2001.

28. Asociación Española de Normalización y Certificación (AENOR). Testing Hardened Concrete_Part 6: Tensile Splitting Strength of Test Specimens 2010; UNE 12390-6:2010; AENOR: Madrid, Spain, 2010.

29. Asociación Española de Normalización y Certificación (AENOR). Thermal Performance of Building Materials and ProductsDetermination of Thermal Resistance by Means of Guarded Hot Plate and Heat Flow Meter Methods: Products of High and Medium Thermal Resistance 2002; UNE-EN 12667:2002; AENOR: Madrid, Spain, 2002.

30. Asociación Española de Normalización y Certificación (AENOR). Testing Fresh Concrete—Part 8: Self-Compacting Concrete-SlumpFlow Test 2020; UNE-EN 12350-8:2020; AENOR: Madrid, Spain, 2020.

31. Asociación Española de Normalización y Certificación (AENOR). Testing Fresh Concrete—Part 9: Self-Compacting Concrete—VFunnel Test 2011; UNE-EN 12350-9:2011; AENOR: Madrid, Spain, 2011.

32. Asociación Española de Normalización y Certificación (AENOR). Testing Fresh Concrete—Part 10: Self-Compacting Concrete—L Box Test 2011; UNE-EN 12350-10:2011; AENOR: Madrid, Spain, 2011.

33. Asociación Española de Normalización y Certificación (AENOR). Testing Fresh Concrete—Part 12: Self-Compacting Concrete-J-Ring Test 2011; UNE-EN 12350-12:2011; AENOR: Madrid, Spain, 2011.

34. Okamura, H.; Ozawa, K. Mix design for self-compacting concrete. Concr. Libr. JSCE 1995, 25, 107-120.

35. De Larrard, F. A method for proportioning high-strength concrete mixtures. Cem. Concr. Aggreg. 1990, 12, 47-52. [CrossRef]

36. Billberg, P.; Petersson, Ö.; Österberg, T. Full Scale Casting of Bridges with Self-Compacting Concrete. In First International RILEM Symposium on Self-Compacting Concrete; Skarendahl, A., Petersson, O., Eds.; RILEM Publications: Stockholm, Sweden, 1999; pp. 639-650.

37. Siddique, R.; Klaus, J. Influence of metakaolin on the properties of mortar and concrete: A review. Appl. Clay Sci. 2008, 43, 392-400. [CrossRef]

38. Domone, P.L.; Jin, J.H.-W.; Chai Ravindra, K.; Dhir Jones, M.R. Optimum Mix Proportioning of Self Compacting Concrete. In Innovation in Concrete Structures: Design and Construction; ASCE Press: Reston, VA, USA, 1999; pp. $277-285$.

39. Rixom, M. Aditivos Para los Hormigones: Composición, Propiedades y Empleo; Editores Asociados: Barcelona, Spain, 1984.

40. Gettu, R.; Agullo, L. Estado del arte del hormigón autocompactable y su caracterización: Parte II. Cem. Hormigón 2004, 862, 32-55.

41. American Concrete Institute. 211.4R-08: Guide for Selecting Proportions for High-Strength Concrete Using Portland Cement and Other Cementitious Materials; American Concrete Institute: Farmington Hills, MI, USA, 2008.

42. Asociación Española de Normalización y Certificación (AENOR). Concrete Tests_Determination of the Modulus of Elasticity in Compression; UNE 83316:1996; AENOR: Madrid, Spain, 1996.

43. Asociación Española de Normalización y Certificación (AENOR). Products and Systems for the Protection and Repair of Concrete Structures-Test Methods-Determination of Modulus of Elasticity in Compression; UNE-EN 13412:2008; AENOR: Madrid, Spain, 2008.

44. Asociación Española de Normalización y Certificación (AENOR). Testing Hardened Concrete—Part 7: Density of Hardened Concrete; UNE-EN 12390-7:2001; AENOR: Madrid, Spain, 2001.

45. American Society for Testing and Materials (ASTM). Standard Test Method for Density, Absorption, and Voids in Hardened Concrete; ASTM C-642/06; ASTM: West Conshohocken, PA, USA, 2006.

46. Asociación Española de Normalización y Certificación (AENOR). Methods of Test for Dense Shaped Refractory Products-Part 10: Determination of Permanent Change in Dimensions on Heating; UNE-EN 993-10:2020; AENOR: Madrid, Spain, 2020.

47. Ramos, D.C. El Sistema de Control del Hormigón en la Normativa Española: Evolución y Futuro; Congr. Int. Estructuras; Asociación Española de Ingeniería Estructural (ACHE): Madrid, Spain, 2014.

48. Asociación Española de Normalización y Certificación (AENOR). Testing Hardened Concrete—Part 4: Compressive Strength— Specification for Testing Machines; UNE-EN 12390-4:2001; AENOR: Madrid, Spain, 2001.

49. Asociación Española de Normalización y Certificación (AENOR). Thermal Performance of Building Materials and ProductsDetermination of Thermal Resistance by Means of Guarded Hot Plate and Heat Flow Meter Methods: Dry and Moist Products of Medium and Low Thermal Resistance; UNE-EN 12664:2002; AENOR: Madrid, Spain, 2002.

50. American Concrete Institute. Self-Consolidating Concrete; 237R-07; ACI: Farmington Hills, MI, USA, 2007.

51. American Concrete Institute Committee 363. High-Strength Concrete (ACI 363R); ACI: Farmington Hills, MI, USA, 2005; pp. 79-80.

52. Ashtiani, M.S.; Scott, A.N.; PDhakal, R. Mechanical and fresh properties of high-strength self-compacting concrete containing class C fly ash. Constr. Build. Mater. 2013, 47, 1217-1224. [CrossRef]

53. González-Roubaud, E.; Pérez-Osorio, D.; Prieto, C.; Rodríguez-Montero, J.; Bailón-Pérez, L.J. High-Strength Self-Compacting Concrete and Method for the Production Thereof. International Patent Application No. WO2015/055878Al, 23 April 2015.

54. Dreux, G.; Festa, J. Nouveau Guide du Beton et de ses Constituents; Eyrolles: Paris, France, 1998. 
55. García-Pérez, J. Diseño de Hormigones Dirigido a la Aplicación. Minor Thesis, Universitat Politècnica de Catalunya (UPC), Barcelona, Spain, 2004.

56. Massazza, F. Pozzolana and Pozzolanic Cements. In Lea's Chemistry of Cement and Concrete; Hewlett, P., Ed.; ButterworthHeinemann: London, UK, 2003; pp. 471-635.

57. Alonso, M.C.; Vera-Agullo, J.; Guerreiro, L.; Flor-Laguna, V.; Sanchez, M.; Collares-Pereira, M. Calcium aluminate based cement for concrete to be used as thermal energy storage in solar thermal electricity plants. Cem Concr. Res. 2016, 82, 74-86. [CrossRef]

58. Bazant, Z.P.; Kaplan, M.F. Concrete at High Temperatures: Materials Properties and Mathematical Models; Longman: London, UK, 1996.

59. Spanish Government. Código Técnico de la Edificación (CTE)—Documento Básico de Seguridad Estructural (SE); Spanish Government: Madrid, Spain, 2006

60. Cubaud, J.C.; Murat, M. Fabricación industrial de arcilla expandida. Materiales de Construcción 1969, 19, 5-16. [CrossRef]

61. González-Roubaud, E.; Pérez-Osorio, D.; Prieto, C.; Girbes-Clari, I.; Ordóñez-Belloc, L.M. Refractory Concrete Composition. International Patent Application No. WO2015055879Al, 23 April 2015. 